\title{
WestVirginiaUniversity
}

THE RESEARCH REPOSITORY @ WVU

Graduate Theses, Dissertations, and Problem Reports

2001

\section{Mutagenicity of root canal sealer RSA Roekoseal Automix in the Ames test}

Joseph Anthony Wateska

West Virginia University

Follow this and additional works at: https://researchrepository.wvu.edu/etd

\section{Recommended Citation}

Wateska, Joseph Anthony, "Mutagenicity of root canal sealer RSA Roekoseal Automix in the Ames test" (2001). Graduate Theses, Dissertations, and Problem Reports. 1277.

https://researchrepository.wvu.edu/etd/1277

This Thesis is protected by copyright and/or related rights. It has been brought to you by the The Research Repository @ WVU with permission from the rights-holder(s). You are free to use this Thesis in any way that is permitted by the copyright and related rights legislation that applies to your use. For other uses you must obtain permission from the rights-holder(s) directly, unless additional rights are indicated by a Creative Commons license in the record and/ or on the work itself. This Thesis has been accepted for inclusion in WVU Graduate Theses, Dissertations, and Problem Reports collection by an authorized administrator of The Research Repository @ WVU. For more information, please contact researchrepository@mail.wvu.edu. 
MUTAGENICITY OF ROOT CANAL SEALER RSA ROEKOSEAL AUTOMIX IN THE AMES TEST

\author{
BY \\ Joseph Anthony Wateska, D.M.D. \\ Thesis Submitted to the School of Dentistry \\ of West Virginia University \\ In Partial Fulfillment of the Requirements
}

For the Degree of

\author{
Masters of Science \\ In \\ Endodontics
}

John G. Thomas, PhD, Chair

C. Russell Jackson, DDS, MS

Norton P. Smith, DDS, MA

Department of Endodontics

Morgantown, West Virginia
2001

Keywords: Endodontics, RSA Roekoseal Automix Root canal sealer, AH Plus root canal sealer, Mutagenicity, Cytotoxicity 


\title{
ABSTRACT \\ MUTAGENICITY OF ROOT CANAL SEALER RSA ROEKOSEAL AUTOMIX IN THE AMES TEST
}

\author{
By Joseph Anthony Wateska, DMD
}

The mutagenic activity of the root canal sealing cement, RSA Roekoseal Automix, was tested in the bacterial gene mutation assay (Ames test). Root canal sealing cement AHPlus was also tested and used as a comparison. Both materials were mixed according to the manufacturer's instruction and tested immediately after mixing and after a setting time of $24 \mathrm{~h}$ at $37^{\circ} \mathrm{C}$ in a $100 \%$ humidified chamber. The set material was powdered and both the freshly mixed and powdered material were eluted in dimethyl sulfoxide (DMSO) for $24 \mathrm{~h}$ at $37^{\circ} \mathrm{C}$. Aliquots of serially diluted eluates were then used in the standard plate incorporation assay. The Salmonella typhimurium tester strains TA98 and TA100 were used to detect the induction of frameshift mutations and base pair substitutions both in the presence and absence of a metabolically active microsomal fraction from rat liver (S9 fraction). No mutagenic or toxic effects were found with DMSO eluates of freshly mixed or 24h set RSA Roekoseal Automix. However, DMSO eluates of the freshly mixed and $24 \mathrm{hr}$ set AHPlus was mutagenic in tester strain TA98 at higher concentrations in a dose related manner. Eluates of the freshly mixed AHPlus were mutagenic in tester strain TA 100 in a dose related manner in the absence of metabolically active S9 fraction. Eluates of the AHPlus material set for $24 \mathrm{~h}$ were mutagenic in the tester strain TA100 in a dose related manner in the presence and absence of S9. The AHPlus set material was more toxic than the freshly mixed material at higher concentrations. Therefore, we conclude that RSA Roekoseal Automix is nonmutagenic and nontoxic in $\underline{\text { S. typhimurium TA98 and }}$ TA100. Also, both freshly mixed and 24h set RSA Roekoseal Automix is less mutagenic than AHPlus in TA98 and TA100 with and without the presence of S9 mix. 
I would like to dedicate this research to my father, Joseph G. Wateska Jr., who passed away June 28, 1997. He was my role model in life and always offered encouragement when dearly needed. He will always be in my mind and in my heart. Thanks Dad, I will always love you and continue to make you proud. To my mother, Kathleen Wateska, I thank you for always being there for me and giving me constant support and confidence. I will forever be indebted for the preparation, love, and encouragement I have received throughout my life. Without you, mom and dad, I could not have achieved nearly as much in life. To my brothers, Jack, Mark, and Gary Wateska, for your continuous support and for being such great big brothers. To my fiancée, Amy Cabe, for giving support, love and confidence throughout my residency and for being the woman of my dreams. 


\section{ACKNOWLEDGMENTS}

I would like to take this opportunity to thank the following people:

Dr. Russell Jackson, for giving me the opportunity of a lifetime and for his expertise in helping me become an endodontist.

Dr. John Thomas, for your guidance, patience, and inspiration, and for chairing my committee.

Dr. Norton Smith, for your help in serving on my committee.

Dr. Raynes, for your support and camaraderie.

Dr. Jason Hales, for your time, effort, and help in performing the Ames test.

Drs. Neil Miller, Catherine Connor, and Steve Moore for your friendship and support. You have all been fun to work with and I wish you all much success.

Marylin Powley, Cathy Myers, and Gina White for being great help, patient and kind.

Dr. William Wallace, Dr. Michael Keane and Dr. Mingzhen Cui for generously helping me with the Ames test.

Dr. Dan Chilko for helping me with the statistical analysis and making sense of the data. Ngoni for helping me with the computer technology. 


\section{TABLE OF CONTENTS}

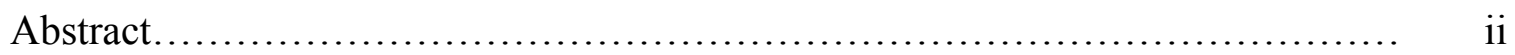

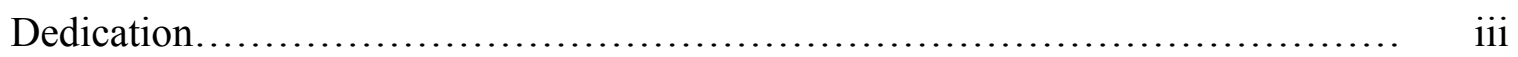

Acknowledgments.................................................... iv

Table of Contents.................................................... v

List of Tables.......................................................... vi

List of Figures........................................................ vii

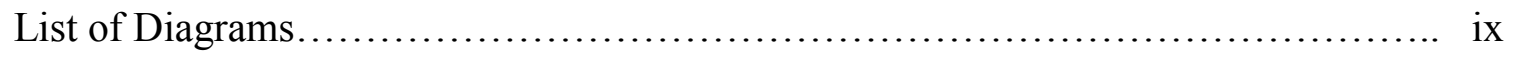

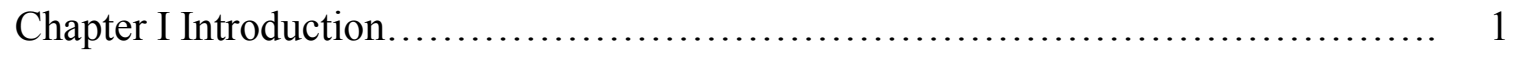

Chapter II Review of Literature............................................ 7

Chapter III Materials and Methods....................................... 15

Chapter IV Results and Discussion...................................... 28

Chapter V Summary and Conclusions..................................... 32

References........................................................... 34

Appendix A........................................................... 38

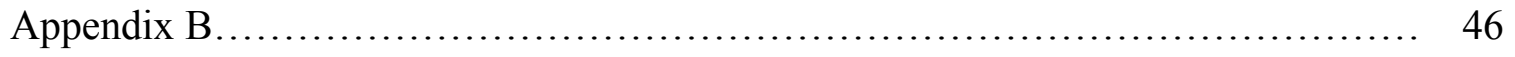

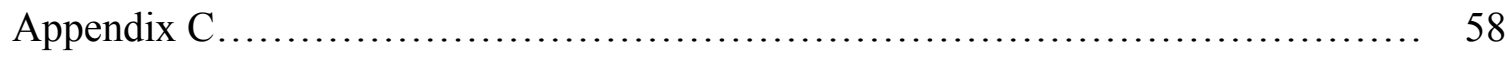

Curriculum Vitae.................................................... 61 


\section{LIST OF TABLES}

$\begin{array}{lll}\text { Table 1. AHPlus and Ingredients } & 16\end{array}$

Table 2. RSA Roekoseal Automix and Ingredients 16

Table 3. Mutagenicity of freshly mixed AHPlus 39

Table 4. Mutagenicity of 24 hour set AHPlus 40

Table 5. Mutagenicity of freshly mixed RSA Roekoseal Automix 41

Table 6. Mutagenicity of 24 hour set RSA Roekoseal Automix 42

Table 7. Mutagenicity of negative control DMSO 43

Table 8. Mutagenicity of positive control 2AA 43

Table 9. Mutagenicity of positive control 1-NP 43

Table 10. Ames test background lawn condition 44

Table 11. Mutagenicity data of freshly mixed AHPlus 47

Table 12. Mutagenicity data of AHPlus after setting 24h. 47

Table 13. Mutagenicity data of freshly mixed RSA Roekoseal Automix. 48

Table 14. Mutagenicity data of RSA Roekoseal Automix after setting 24h. 48

Table 15. Statistical analysis of AHPlus after mixing in TA100 w/ S9 49

Table 16. Statistical analysis of AHPlus after mixing in TA100 w/o S9 49

Table17. Statistical analysis of AHPlus after setting 24h in TA100 w/ S9 50

Table18. Statistical analysis of AHPlus after setting 24h in TA100 w/o S9. 50 


\section{LIST OF TABLES (CONT)}

Table19. Statistical analysis of AHPlus after mixing in TA98 w/o S9.

Table 20. Statistical analysis of AHPlus after mixing in TA98 w/ S9.

Table 21. Statistical analysis of AHPlus after setting $24 \mathrm{~h}$ in TA98 w/o S9

Table 22. Statistical analysis of AHPlus after setting 24h in TA $98 \mathrm{w} / \mathrm{S} 9$.

Table 23. Statistical analysis of RSA after mixing in TA98 w/o S9.

Table 24. Statistical analysis of RSA after mixing in TA98 w/ S9.

Table 25. Statistical analysis of RSA after setting $24 \mathrm{~h}$ in TA98 w/ S9.

Table 26. Statistical analysis of RSA after setting $24 \mathrm{~h}$ in TA98 w/o S9.

Table 27. Statistical analysis of RSA after mixing in TA100 w/ S9.

Table 28. Statistical analysis of RSA after mixing in TA100 w/o S9.

Table 29. Statistical analysis of RSA after setting 24h in TA100 w/ S9.

Table 30. Statistical analysis of RSA after setting $24 \mathrm{~h}$ in TA100 w/o S9.

Table 31. Analysis of variance for TA98 and TA100. 


\section{LIST OF FIGURES}

Page

$\begin{array}{lll}\text { Figure 1. } & \text { Base-pair Substitution } & 13\end{array}$

$\begin{array}{lll}\text { Figure 2. } & \text { Frameshift Mutation } & 14\end{array}$

Figure 3. Serial Dilution of RSA Roekoseal Automix $\quad 17$

$\begin{array}{llr}\text { Figure 4. Preparation of S9 Mixture } & 20\end{array}$

Figure 5. Flowchart of the Ames Test using RSA Roekoseal Automix 23

Figure 6. Example of revertant colonies and inverted microscope. 25 


\section{List of Diagrams}

Page

Diagram 1. Mutagenicity of freshly mixed RSA Roekoseal and AHPlus in TA98. 59

Diagram 2. Mutagenicity of freshly mixed RSA Roekoseal and AHPlus in TA100 59

Diagram 3. Mutagenicity of 24h set RSA Roekoseal and AHPlus in TA98 60

Diagram 4. Mutagenicity of $24 \mathrm{~h}$ set RSA Roekoseal and AHPlus in TA100 60 


\section{CHAPTER I \\ INTRODUCTION}

\section{BACKGROUND}

Elimination of microorganisms from the root canal system by instrumentation and irrigation is essential for the overall success of root canal therapy. The antimicrobial activity of root canal sealers helps to play an important rule in the elimination of any remaining bacteria (18). Substances present in some of the sealers such as paraformaldehyde, eugenol, and thymol help to destroy these bacteria (1). On the other hand, these endodontic filling materials may have a toxic and mutagenic affect on the periapical soft tissues, thereby canceling the potential benefits of the antimicrobial properties of the materials (2). Various studies have revealed that elutable substances or degradation or corrosion products from root canal fillings may gain access to surrounding tissues through various connections, e.g., dentinal tubules, accessory and lateral canals, and apical foramina (3).

It has been demonstrated that zinc oxide eugenol-containing materials were moderately to severely toxic in implant studies. Severe inflammation was observed when the cements were injected into subcutaneous connective tissue of rabbits (4). Whereas, formaldehyde-containing materials have been shown to induce severe periapical inflammation even after a few months' observation period (5). In contrast to these findings, a glass ionomer root canal sealer (Ketac-Endo) was tissue compatible, with only 
a mild inflammatory reaction after exposure for five days (6). Calcium hydroxide-based filling sealers have shown mild to moderate tissue-irritating activities and have been demonstrated to have no mutagenic potential $(4,15)$. No formaldehyde or other marked cytotoxic and mutagenic ingredients are known to be released from the calcium hydroxide based sealers, e.g., Sealapex and Apexit (9). AH26, a resin-based sealer, caused severe tissue inflammation after only a few days in various biocompatibility studies, however, only mild tissue reactions were reported from long- term investigations (7). AH26 has been shown to release formaldehyde after mixing, with a maximum release after 2 days (8).

The mutagenic effects of root canal sealers have been addressed in the past. A resinbased material, AH26, was mutagenic in the Salmonella/microsome assay (Ames Test) and when tested in mammalian cells in vitro $(10,11,15)$. It was determined that bisphenol A diglycidylether was the most likely mutagenic component of a resin-based material, although formaldehyde could have added to this effect (12). The mutagenicity of AH Plus was also tested in a bacterial gene mutation assay, the Ames test. This study concluded that AHPlus was mutagenic under certain experimental conditions and that more than likely the epoxy resin present in this sealer was the mutagenic component (13). Whereas, another similar test concluded that AHPlus was mutagenic dependant upon the setting period after mixing (22).

Many endodontic materials have been tested over the years for there mutagenic effects, but no studies have tested the mutagenicity of RSA Roekoseal Automix (Roeko USA, Monrovia, CA). RSA Roekoseal Automix is a polydimethylsiloxane based root canal sealer that has been recently introduced for root canal therapy. 
In the present study, the mutagenicity of the polydimethylsiloxane based RSA Roekoseal Automix and resin based AHPlus (Dentsply USA, York, PA) root canal sealer will be tested immediately after mixing and after a setting time of $24 \mathrm{~h}$. Two different Salmonella typhimurium tester strains, TA98 and TA100, will be used to investigate material-induced gene mutations via the Ames test, reverse-mutation assay.

\section{STATEMENT OF PROBLEM}

Root canal sealers are routinely used in conventional root canal therapy. Some endodontic materials have been shown to have a mutagenic potential to the surrounding periradicular tissues. Will a new root canal sealer, RSA Roekoseal Automix have a mutagenic potential?

\section{SIGNIFICANCE OF THE PROBLEM}

Adverse material effects may play an important role in the failure of endodontic treatment, even if no major fault can be identified in treatment. Therefore, only those root canal sealers that are biocompatible and display no mutagenic potential should be used in conventional root canal therapy. This demands that each endodontic material should be evaluated for its mutagenic potential before clinical application. For example, sealers with inferior biocompatibility, such as formaldehyde-releasing materials, should no longer be applied during treatment. RSA Roekoseal Automix, a new polydimethylsiloxane endodontic sealer, claims to be a superior endodontic sealer when compared to others. However, the mutagenic potential of RSA Roekoseal Automix has not been determined. If RSA Roekoseal Automix can be shown to be non-mutagenic as 
defined by the Ames test, perhaps it can be accepted for use in conventional root canal therapy.

\section{HYPOTHESIS}

RSA Roekoseal Automix will be non mutagenic as evaluated by the Ames test, reverse-mutation assay.

RSA Roekoseal Automix will be less mutagenic than AHPlus as evaluated by the Ames test, reverse-mutation assay.

\section{OPERATIONAL DEFINITIONS}

The following terms are defined for clarification:

1. Mutagenicity - The property of being able to induce genetic mutation.

2. Root canal sealer - A radiopaque dental cement used, usually in combination with a solid or semi-solid core material, to fill voids and to seal root canals during obturation.

3. Anaerobe - a microorganism that lives and grows in complete, or almost complete, absence of molecular oxygen.

4. Gram-negative - losing the stain or decolorized by alcohol in Gram's method of staining, a primary characteristic of certain microorganisms.

5. Gram-positive - retaining the stain or resisting decolorization by 
alcohol in Gram's method of staining, a primary characteristic of certain microorganisms.

6. Facultative anaerobe - microorganisms that are able to grow under either anaerobic or aerobic conditions.

7. Obligate anaerobe - microorganisms that are able to grow only in the complete absence of molecular oxygen; some are killed by oxygen.

8. Frameshift Mutation - mutations which result in an addition $(+)$ or deletion (-) of one or more nucleotides in a sequence of mRNA causing a reading frameshift of the trinucleotide sequences.

9. Base-pair substitution - The replacement of a single base in DNA by by another base, causing a mutation.

10. Auxotrophic bacteria - Bacteria requiring a growth factor that is not required by the parental or prototype strain; said of microbial mutants.

11. Eluate - The substance separated out by, or the product of elution.

\section{LIMITATIONS}

1. This study was conducted using an in vitro model

2. It was not the intent to simulate exact clinical populations of bacteria but use certain quantified bacteria only as a measuring tool to determine the mutagenicity of RSA Roekoseal Automix, and AHPlus.

3. The tester strains used in the Ames test are of non-endodontic origin. 


\section{DELIMITATIONS}

1. The endodontic sealers used were RSA Roekoseal Automix (Roeko USA, Monrovia, CA), and AHPlus (Dentsply USA, York, PA).

\section{ASSUMPTIONS}

Elimination of the microorganisms from the root canal system is essential to the overall success of conventional root canal therapy.

Endodontic sealers are useful in limiting micro leakage of the root canal system.

The Ames test, reverse mutation gene assay, is an accepted method for testing the potential of material-induced gene mutations. 


\section{CHAPTER II}

\section{REVIEW OF LITERATURE}

Elimination of microorganisms from the root canal system is crucial in the overall success of conventional root canal therapy. Repair of the periapical area has been reported where sufficient removal of large numbers of organisms together with inflamed necrotic tissue and inflammatory products has been accomplished by mechanical and chemo mechanical cleansing and debridement (35)(36). Bacteria and their bi-products that stimulate organic reactions are the main cause of pathological changes in the root canal and associated periapical areas. Low oxygen tension, nutrient supply, and loss of natural defense after pulpal necrosis, benefit microorganism interaction (37) (38).

Anaerobic and aerobic flora has been isolated from endodontic infections. In 1997,

Chaudhry, Kalra, Talwar and Thakur evaluated microbiological and clinical data from 56 patients with endodontic infections. Forty-nine positive cultures were obtained from the 56 consecutive necrotic root canal systems, which were sampled. Aerobic bacteria were isolated from $72 \%$, anaerobic bacteria from $6 \%$ and mixed aerobic and anaerobic bacteria from $22 \%$ of the samples. The most common aerobic isolate was Klebsiella pneumonia while Bacteroides was the most common anaerobic species. Their results illustrated the poly-microbial nature of endodontic infections and the role of anaerobic bacteria (16). In 1999, Baumgartner, Watkins, Bae and Xia were able to isolate black-pigmented bacteria 
(i.e. Prevotella and Porphyromonas species) from endodontic infections through conventional laboratory methods. Black pigmented bacteria were shown to be associated with purulent drainage either from the root canal or an associated sinus tract (17). E. faecalis is among the few facultative organisms associated with persistent periapical inflammation (39). This facultative organism has shown to be resistant to treatment (40). B. fragilis can also be cultured from endodontic lesions and is representative of a gramnegative obligate rod (16).

In addition to having good sealing ability, and in order to minimize the incidence of local and/or systemic side effects, the biocompatibility of all endodontic materials should be analyzed by various in vitro and in vivo tests prior to clinical implication (23) (24). The various in vitro tests include determination of antimicrobial effects, cytoxicity, and mutagenicity of root canal sealers. In 1980, Grossman studied the antimicrobial effect of eleven root canal cements. These cements were tested aerobically by the agar diffusion method for their antimicrobial effect. Both those of the zinc oxide-type and of the plastic-type exerted antimicrobial activity to a varying degree. Those cements containing paraformaldehyde were more effective than those that did not contain this ingredient. However, the effect of paraformaldehyde diminished with time (18).

In 1997, Fuss and Shalhav studied the antibacterial activity of calcium hydroxidecontaining endodontic sealers on Enterococcus faecalis in vitro. They showed that the antimicrobial activity of each tested sealer changes differently with the time interval between mixing and testing, suggesting different physicochemical properties and potentially diverse clinical applications (19). 
Although many sealers may have antimicrobial activities, they have also been shown to exert cytotoxic affects on the surrounding periapical tissues. In 1990, Briseno and Willershausen examined six different zinc oxide eugenol root canal sealers to determine their cytotoxicity on human gingival fibroblasts. They found that these root canal sealers were highly toxic to human gingival fibroblasts (20). In 1998, Osorio et al. used an in vitro cell culture model of human gingival fibroblasts and L-929 cells to measure the cytotoxicity of currently used root canal sealers Endomet, CRCS, and AH26. Statistical analysis of the results showed that CRCS was the least cytotoxic sealer followed by Endomet and AH26 (21).

Genotoxicity, mutagenicity and carcinogenicity are important factors affecting the systemic compatability of an endodontic material. Genotoxicity means the presence of a DNA-reactive component that may result in mutagenicity and carcinogenicity (25). Due to the extremely serious and life threatening consequences, mutagenicity and carcinogenicity are gaining increased public interest. Therefore, In vitro test systems for genotoxicity have been used and can be differentiated into bacterial tests such as the classic Ames test and the Umu test, and eukaryotic tests such as the DNA synthesis inhibition test, the chromosomal aberration test, and the hypoxanthine-guanine phosphoribosyltransferase test (HPGRT)(26) (27) (28). In 1985, Orstavik and Hongslo studied the mutagenicity of four endodontic sealers by using the Ames test. Extracts of a synthetic polymer material, based on epoxy-bis-phenol A, induced mutations in the Salmonella typhimurium TA100 as did extracts of the epoxy-bis-phenol A resin alone. Formaldehyde, an active ingredient from one of the $\mathrm{ZnO}$-based materials, induced mutations in both Salmonella typhimurium TA98 and TA100 (29). 
In 1999, Leyhausen et al. tested the cytotoxic and genotoxic effects of AHPlus by means of the growth inhibition test with primary human periodontal ligament fibroblasts and permanent 3T3 monolayers, the prokaryotic umu test, the eucaryotic DNA synthesis inhibition test and the in vivo alkaline filter elution test. These tests results revealed that AHPlus was neither genotoxic nor mutagenic (30). Shweikl also tested the mutagenicity of AH26 in an in vitro mammalian cell mutation assay. They concluded that eluates of mixed AH26 were toxic and mutagenic, and both effects strongly depended on the setting time. The mutagenic activity of the mixed AH26 was clearly reduced after a setting time of one week (31). In 1996, Heil et al. demonstrated through three test methods, the bacterial umu-test, the eukaryotic DNA synthesis inhibition test, and the in vivo alkaline filter elution technique that AH26 elicited clear concentration- related genotoxic responses (26).

In 1998, Schweikl et al showed that in addition to the root canal sealer AHPlus being mutagenic after initial mixing to tester stain TA100 in a dose related manner, it was also toxic in the presence of dimethyl sulfoxide (DMSO) and S9 (metabolically active microsomal fraction of rat liver) in the Ames test (22). In 1997, Geurtsen et al. stated that, "since various dental or endodontic materials are highly cytotoxic, it is a basic requirement that genotoxicity tests easily quantify cytotoxicity simultaneously, in order to avoid misinterpretation of the data" (27). In 1999, Ersev et al. determined in vitro the cytotoxic and mutagenic effects of root canal filling cements of various chemical compositions. L-929 mouse fibroblast cell cultures where used in the MTT test to determine the cytotoxicity of various root canal filling materials and the Ames test was used to determine their mutagenicity. He found that mixed silver free AH26 might 
contain small amounts of two mutagenic substances: bisphenol A diglycidyl ether and formaldehyde (32).

The Ames test for endodontic materials is an accepted method of testing for the mutagenicity of endodontic materials. The Ames test is included in the American Dental Association's Specification No. 41 (33), as well as the International Federation's Recommended Standard Practices for Biological Evaluation of Dental Materials (34). The Ames test utilizes a gram-negative rod, Salmonella typhimurium tester strains, TA98 and TA100. Although S. typhimurium is not found in endodontic infections, gramnegative rods are commonly cultured from endodontic lesions (16).

The salmonella test was first validated in a study of 300 chemicals, most of which were known carcinogens (41). All validations show that the test fails to detect a few classes of carcinogens such as polychlorinated pesticides. But the addition of cofactor S9 mix (rat liver enzymes) allows a detection of a wider variety of carcinogens requiring metabolic activation. In 1981 Ames and McCann estimated the correlation between mutagenicity and carcinogenicity to be approximately $83 \%$ (42).

TA 98 and TA100 are histidine-requiring Salmonella typhimurium tester strains that are used in mutagenicity testing. The Ames test detects a histidine mutation in TA 100 in the his $\mathrm{G}$ gene coding for the first enzyme of histidine biosynthesis (43). This mutation, determined by DNA sequencing analysis, substitutes proline for leucine in the organism (44). TA100 detect mutagens that cause base pair substitutions (figure 1). The histidine mutation in TA98 is in the his $\mathrm{D}$ gene coding for histidinol dehydrogenase. TA 98 detects various frameshift mutations (figure 2). Spontaneous reversion of the tester strains to histidine independence is measured routinely in mutagenicity experiments (i.e. 
Ames test) and is expressed as the number of spontaneous revertants per plate. The revertant colonies are clearly visible in a uniform background lawn of auxotrophic bacteria (44). 
DNA

mRNA

DNA

mRNA
CTA/GCA/TGA/GAG/GGG GAT/CGA/ACT/CTC/CCC

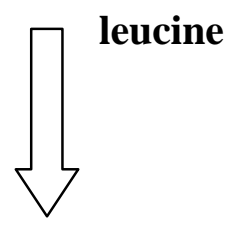

CUA/GCA/UGA/GAG/GGG

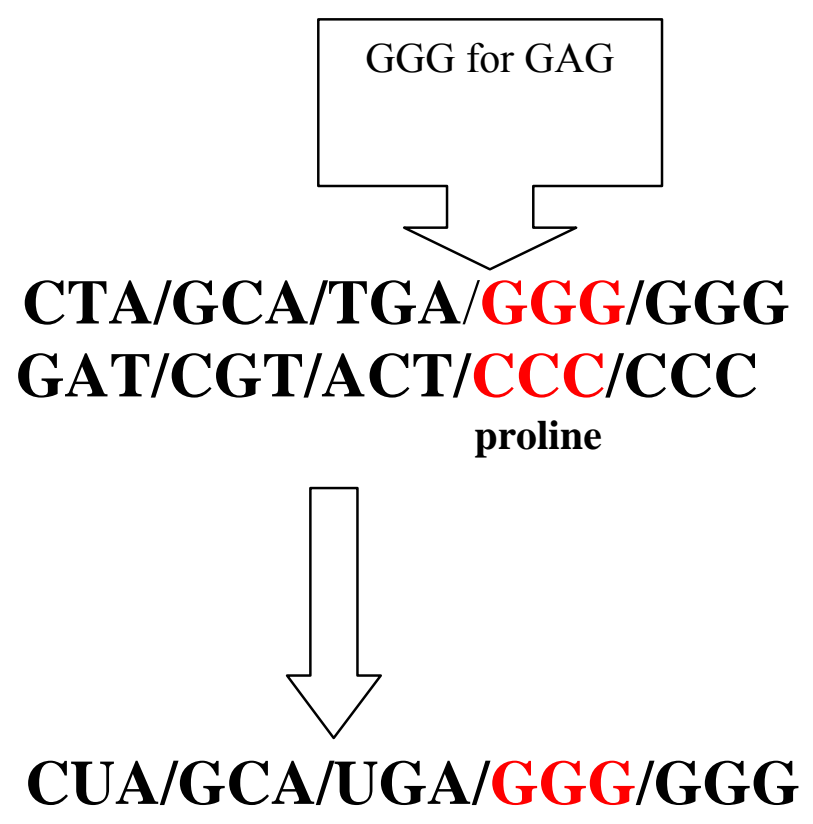

Figure 1. Base-pair substitution 
DNA

mRNA

DNA

mRNA

CTA/GCA/TGT/ATA/GGG GAT/CGT/ACA/TAT/CCC

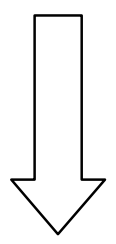

CUA/GCA/UGU/AUA/GGG

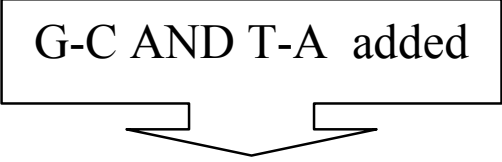

CTA/GGT/CAT/GTA/TAG/GG GAT/CCA/GTA/CAT/ATC/CC

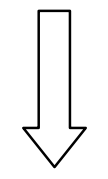

CUA/GGU/CAU/GUA/UAG/GG

Figure 2. Frameshift mutation 


\section{CHAPTER III}

\section{MATERIALS AND METHODS}

\section{SAMPLE DESCRIPTION}

This study involved two root canal sealers, RSA Roekoseal Automix (Langenau, Germany) and AHPlus (York, PA). The composition of RSA Roekoseal Automix and AHPlus, which was tested in this study, is shown in Table 1 and Table 2. The materials were mixed according to the manufacturers instructions. For testing the mutagenic potencies in the Ames test, 1gram of each material, RSA Roekoseal Automix and AHPlus, was eluted in 10ml dimethylsulfoxide (DMSO)(Sigma Lot\# 87H3661) for 24 hours at $37^{\circ} \mathrm{C}$ immediately after mixing and after a setting period of $24 \mathrm{~h}$ at $37^{\circ} \mathrm{C}$ in $100 \%$ humidity. The set material was ground in a mortar before elution. Each sample was vortexed for 2 minutes immediately after eluting in DMSO. After setting for $24 \mathrm{~h}$, each sample was serially diluted to final concentrations of $10,5,2.5,1.25, .625$ and $.312 \mathrm{mg} / 0.1 \mathrm{ml}(\mathrm{mg} / \mathrm{plate})($ Figure 3$)$. Each sample was stored in $-20^{\circ} \mathrm{C}$ until the Ames test was performed. Positive controls, 2-Aminaoanthracene (2AA) and 1-Nitropyrene (1NP), were used to confirm the reversion properties of each strain and efficacy of the microsomal fraction from the rat liver (S9). DMSO was used as the negative control. 


\begin{tabular}{|c|c|c|}
\hline Material & Components & Ingredients \\
\hline \multirow[t]{2}{*}{$\begin{array}{l}\text { AHPlus (lot \# } \\
\text { 0009000417) } \\
\text { (Dentsply, USA, } \\
\text { York, PA) }\end{array}$} & $\begin{array}{l}\text { AHPlus Paste A } \\
\text { (lot0009000417) }\end{array}$ & $\begin{array}{l}\text { Epoxy resin } \\
\text { Calcium tungstate } \\
\text { Zirconium oxide } \\
\text { Aerosil } \\
\text { Iron oxide }\end{array}$ \\
\hline & $\begin{array}{l}\text { AHPlus Paste B } \\
(\text { lot 0009000417) }\end{array}$ & $\begin{array}{l}\text { Adamantane amine } \\
\text { N,N'-Dibenzoyl-5-oxanonane-diamine-1,9- } \\
\text { TCD-diamine } \\
\text { Calcium tungstate } \\
\text { Zircomiun oxide } \\
\text { Silicone oil } \\
\text { Aerosil }\end{array}$ \\
\hline
\end{tabular}

Table 1. AHPlus and Ingredients

\begin{tabular}{|l|l|l|}
\hline Material & \multicolumn{1}{|c|}{ Components } & \multicolumn{1}{|c|}{ Ingredients } \\
\hline $\begin{array}{l}\text { RSA Roekoseal } \\
\text { Automix } \\
\text { (lot 2101745) }\end{array}$ & $\begin{array}{l}\text { RSA Roekoseal } \\
\text { Automix Paste A } \\
\text { (Roeko, USA, } \\
\text { Monrovia, CA) }\end{array}$ & $\begin{array}{l}\text { Polydimethylsiloxane } \\
\text { Silicone oil } \\
\text { Paraffin-base oil } \\
\text { Zirconium dioxide (for radiopacity) }\end{array}$ \\
& & \\
& RSA Roekoseal & Hexachloroplatinic acid \\
& Automix Paste B & \\
& (catalyst) & \\
& & \\
& & \\
\end{tabular}

Table 2. RSA Roekoseal Automix and Ingredients 
Serial Dilution of RSA Roekoseal Automix

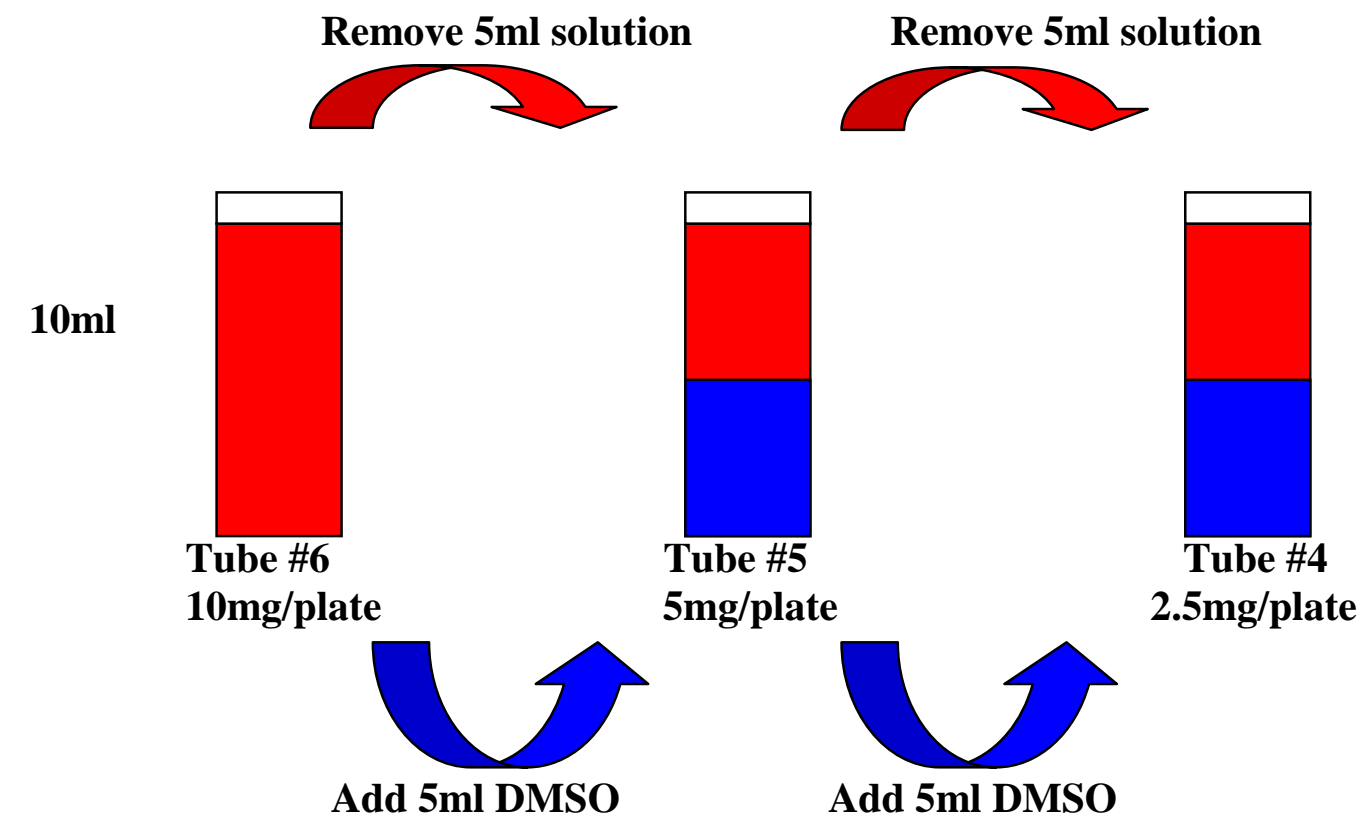

Remove 5ml solution

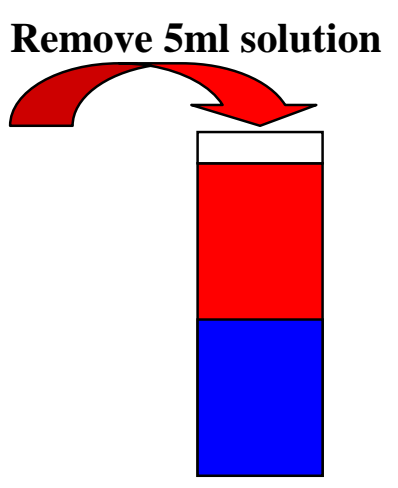

Tube \#3

$1.25 \mathrm{mg} / \mathrm{plate}$

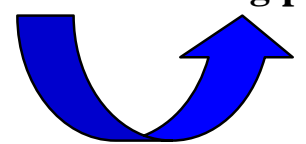

Add 5ml DMSO

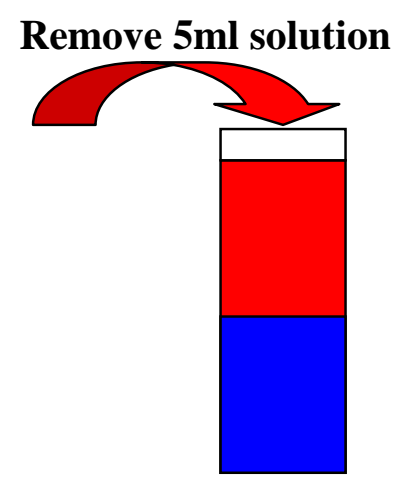

Tube \#2

$0.625 \mathrm{mg} / \mathrm{plate}$

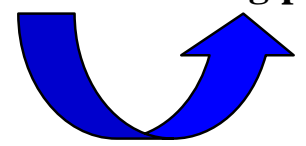

Add 5ml DMSO

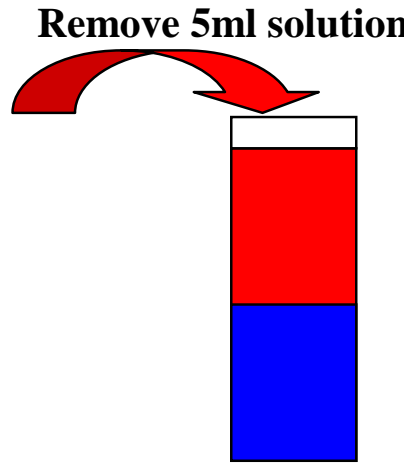

Tube \#1

$0.312 \mathrm{mg} / \mathrm{plate}$

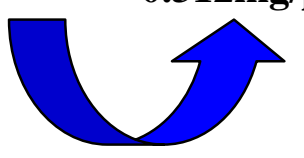

Add 5ml DMSO

Figure 3. Serial dilution of RSA Roekoseal Automix 


\section{RESEARCH DESIGN}

The Ames test, described by Bruce Ames (University of California, Berkely), was employed to test the mutagenicity of a new root canal sealer RSA Roekoseal Automix and a previously tested root canal sealer AHPlus. Each sealer was mixed according to the manufacturer's instructions and tested immediately after mixing and after a setting time of $24 \mathrm{~h}$ at $37^{\circ} \mathrm{C}$ in $100 \%$ humidity.

\section{METHODOLOGY}

Cultures of Salmonella typhimurium tester strains, TA98 and TA100, were kindly provided by Dr. Bruce N. Ames (University of California at Berkeley). The plate incorporation test was carried out as follows:

PREPARATION OF TESTER STRAINS Salmonella typhimurium tester strain, TA98 and TA100 are grown in oxoid nutrient broth No. 2 to a density of $1-2 \times 10^{9}$ cells per ml. DMSO was added as a cryoprotective agent. The amount of culture required for a mutagenicity assay depends on the size of the experiment and is based on $0.1 \mathrm{ml}$ of culture per plate. The cultures were prepared by Dr. Mingzhen Cui from the National Institute of Occupational Safety and Health, Morgantown, WV, and frozen permanent copies were stored at $-80^{\circ} \mathrm{C}$.

PREPARATION OF THE AGAR PLATES Dr. Mingzhen Cui prepared the agar plates 24 hours prior to the experiment. The plates were prepared in accordance with the 
recommendations given by Dr. Bruce N. Ames. Plates for the mutagenicity assay contain $30 \mathrm{ml}$ of minimal glucose agar medium. The medium is $1.5 \%$ Bacto-Difco agar and $2 \%$ glucose in Vogel-Bonner medium E. Sterile, disposable plastic petri plates (100mm x 15mm) (Falcon No.1029) were used.

PREPARATION OF S-9 MIX The S-9 mix was prepared on ice under a sterile hood. The components of the S-9 mix and preparation are as follows:

S9 mixture: These ingredients were added together and kept on ice to prevent loss of activity. The total volume prepared was $60 \mathrm{ml} \mathrm{S-9} \mathrm{mixture.} \mathrm{An} \mathrm{automated} \mathrm{pipette} \mathrm{was}$ used to prepare the required volumes of sample (Figure 4).

$1.2 \mathrm{ml} \mathrm{S}-9$ salt $\left(\mathrm{KCL}^{-}, \mathrm{MgCl} 2\right)$

0.3ml Glucose-6-Phosphate (Stored in $-80^{\circ} \mathrm{C}$ Forma Scientific Bio Freezer prior to use)

2.4ml NADP (Stored in $-80^{\circ} \mathrm{C}$ Forma Scientific Bio Freezer prior to use)

30ml Phosphate Buffer, $\mathrm{pH} 7.4$

20ml sterile $\mathrm{H} 20$

$6.0 \mathrm{ml} \mathrm{S}-9$ microsomal rat liver fraction (lot $\# 1107$ ) (Stored in a freezer at $-80^{\circ} \mathrm{C}$ Forma Scientific Bio Freezer prior to use) 
$1.2 \mathrm{ml} \mathrm{S}-9$ salt

30ml Phosphate buffer

$20 \mathrm{ml}$ sterile $\mathrm{H} 2 \mathrm{O}$

0.3ml Glucose-6-Phosphate

$2.4 \mathrm{ml}$ NADP

$6.0 \mathrm{ml} \mathrm{S}-9$ microsomal liver fraction
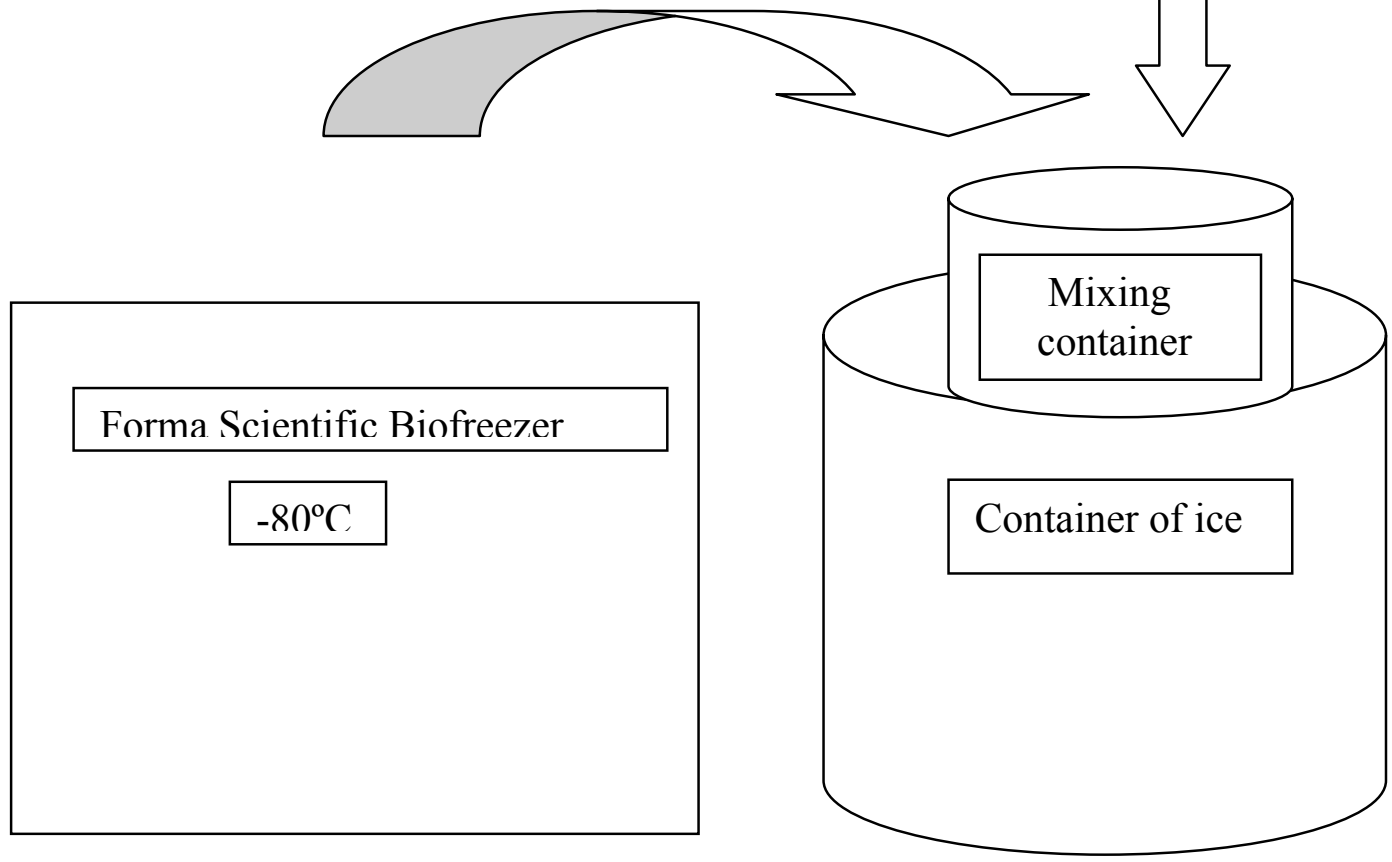

Figure 4. Preparation of S-9 mixture

PREPARATION OF HISTIDINE / BIOTIN MIXTURE Histidine and biotin were required by the tester strains for growth on the agar. $400 \mathrm{ml}$ Top agar containing $0.6 \%$ Difco agar and $0.5 \% \mathrm{NaCL}$ was melted in a microwave oven for $2-3$ minutes. $40 \mathrm{ml}$ $0.5 \mathrm{mM}$ Lhistidine/ biotin was added to the $400 \mathrm{ml}$ top agar and mixed by manually 
swirling the mixture. The mixture was then placed in a water bath at $45^{\circ} \mathrm{C}$ (Precision Scientific, Model 82, Chicago, Il.) and stored there until needed.

PLATE INCORPORATION TEST (AMES TEST) The plate incorporation test consists of combining the test compound, the tester strain, and S-9 mix or physiological saline (without S-9 mix) soft agar and pouring it onto a glucose minimal agar plate. All glassware, reagents, media and petri plates used in the experiment were sterile. All procedures were performed under a SterilGARD III Advance hood (The Baker Company, Samford, Maine).

Each diluted test sample was tested in duplicate, in both tester strains TA98 and TA100 and in the presence and absence of S-9 mix. All testing was performed in accordance with the recommendations given by Bruce N. Ames, Biochemistry department, University of California, Berkeley, CA 94720 (14).

Procedure: $0.1 \mathrm{ml}$ of each serially diluted test sample (AHPlus after mixing, AHPlus after setting 24hours, RSA Roekoseal Automix after mixing and RSA Roekoseal Automix after setting 24hours) was added to a $10 \mathrm{ml}$ test tube with a micropipette. $0.5 \mathrm{ml} \mathrm{S}-9 \mathrm{mix}$, or $0.5 \mathrm{ml}$ physiological saline (without S-9), was added to the test sample. The compound is tested in the presence and absence of S-9 mix. $0.1 \mathrm{ml}$ of the tester strain (TA98 or TA100) was then added to the mixture. After preparing the test sample mixtures, they were vortexed (Vortex Genie 2) for 2 seconds, placed in a rotating tray and incubated at $37^{\circ} \mathrm{C}$ for $20-30$ minutes in a Forma Scientific incubator. The tubes were slowly turned during the incubation. This is known as the pre-incubation phase first 
described by Yahagi et al in 1975 (45). This phase makes the tester strains more sensitive to potential mutagens. After incubation, $2.5 \mathrm{ml}$ of the Histidine/Biotin top agar mixture was added to each test sample using a Brinkmann dispensette. This mixture of test sample, tester strain, S-9 mix or physiological saline and Histidine/Biotin made up the soft (top) agar. Each test component was mixed by vortexing the soft agar for 2-3 seconds at low speed and then poured onto a minimal glucose agar plate. To achieve a uniform distribution of the soft agar on the surface of each plate, the uncovered plate was quickly tilted and rotated. Each plate was covered and placed under the sterile hood to harden. The mixing, pouring, and distribution of each plate took less than 20 seconds and the plates were left to harden for several minutes. Note: If the top agar begins to harden in mid-operation a stippled surface will result which will make scoring of revertants difficult. Belser et al. reported that the greatest source of variability in the test results is non-uniformity of the soft (top) agar thickness (46). Within 1 hour the plates were inverted and placed in a dark, vented, $37^{\circ} \mathrm{C}$ incubator for 48 hours. After 48 hours the revertant colonies on the test plates and control plates were counted 3 separate times, each time being from a different position, on an automated counter (Artek Counter, Model 880, Dynatech Laboratories Inc.). The presence of a background lawn of auxotrophic bacteria on each plate was confirmed by analysis under an inverted microscope (Leica DMIL) at 100x power. The condition of the background lawn was labeled as being either good, fair, poor or toxic. A lawn that was thin compared to the lawn on the negative control plate was evidence of bacterial toxicity. Colonies that appeared without the presence of a background lawn were not revertants and were not counted (figure 5). 
0.5ml S-9 mix (or physiologic saline)

$0.1 \mathrm{ml}$ RSA Roekoseal Automix sample

$0.1 \mathrm{ml}$ TA98 or TA100

Added to $10 \mathrm{ml}$ test tube

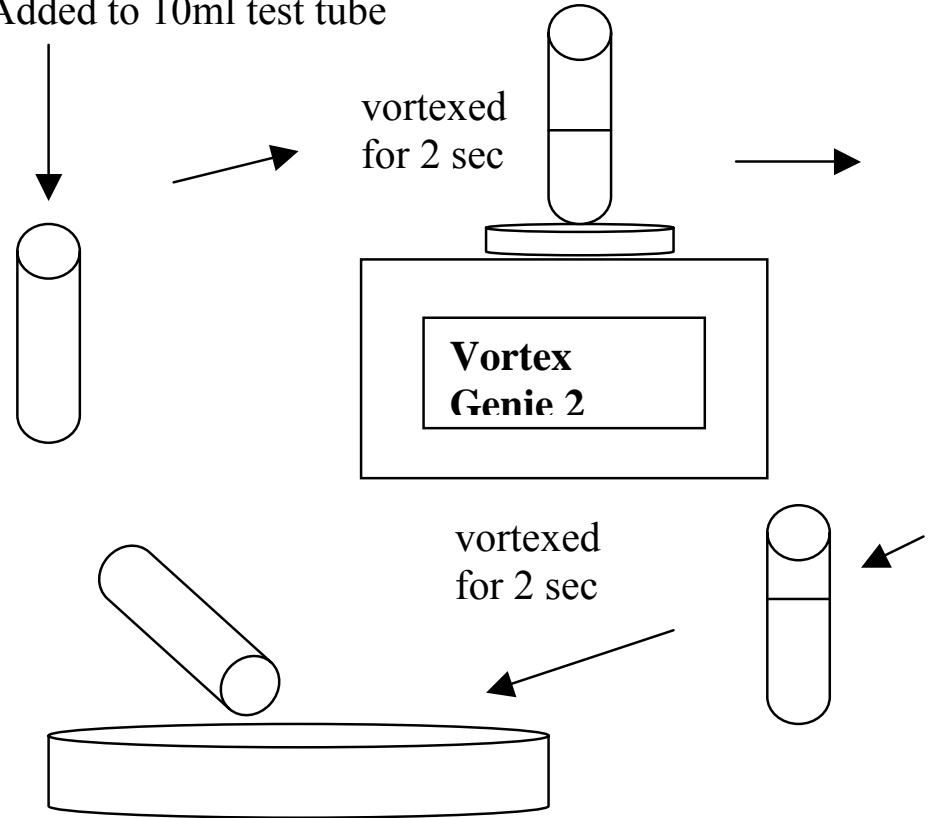

Sample mix is placed in a rotating tray and incubated at $37^{\circ} \mathrm{C}$ for $20-30$ minutes

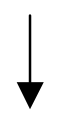

After preincubation 2.5ml Histidine/Biotin top agar mix added

Sample mix is poured onto minimal glucose agar plate, the plate was rotated and allowed to harden for 1 hour. The sample was then allowed to incubate at $37^{\circ} \mathrm{C}$ for $48 \mathrm{hrs}$.

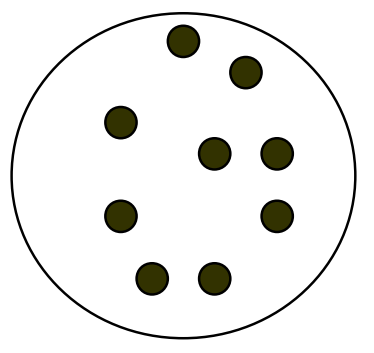

After 48 hours the number of revertant colonies were counted using an automatic counter (Artek).

Figure 5. A Flowchart of the Ames test using the RSA Roekoseal Automix sample. 
SPONTANEOUS REVERSION Spontaneous reversion of the tester strains to histidine independence was measured in the mutagenicity experiment and was expressed as the number of spontaneous revertants per plate. The revertant colonies were clearly visible in a uniform background lawn of auxotroph bacteria. Each tester strain reverted spontaneously at a rate that was characteristic of the strain. The number of revertants that arose in the 48-hour incubation period was dependant on the final number of auxotrophs on the plate and that number was a function of the histidine concentration. The number of auxotrophs was not counted but their number is assumed to be constant due to the constant histidine concentration.

\section{DATA COLLECTION / INSTRUMENTATION}

Raw data sheets were used to collect the number of spontaneous revertants per sampled minimal glucose agar plate as shown in Tables 1-7, Appendix A. An automatic colony counter (Artek) was used to count the number of revertant colonies. The condition of the background lawn for each sample plate was noted on a raw data sheet shown in Table 8, Appendix A. An inverted microscope (Leica, Germany), set at a power of 100x was used to observe the condition of the background lawn as being either good, fair, poor or toxic (Figure 6). 

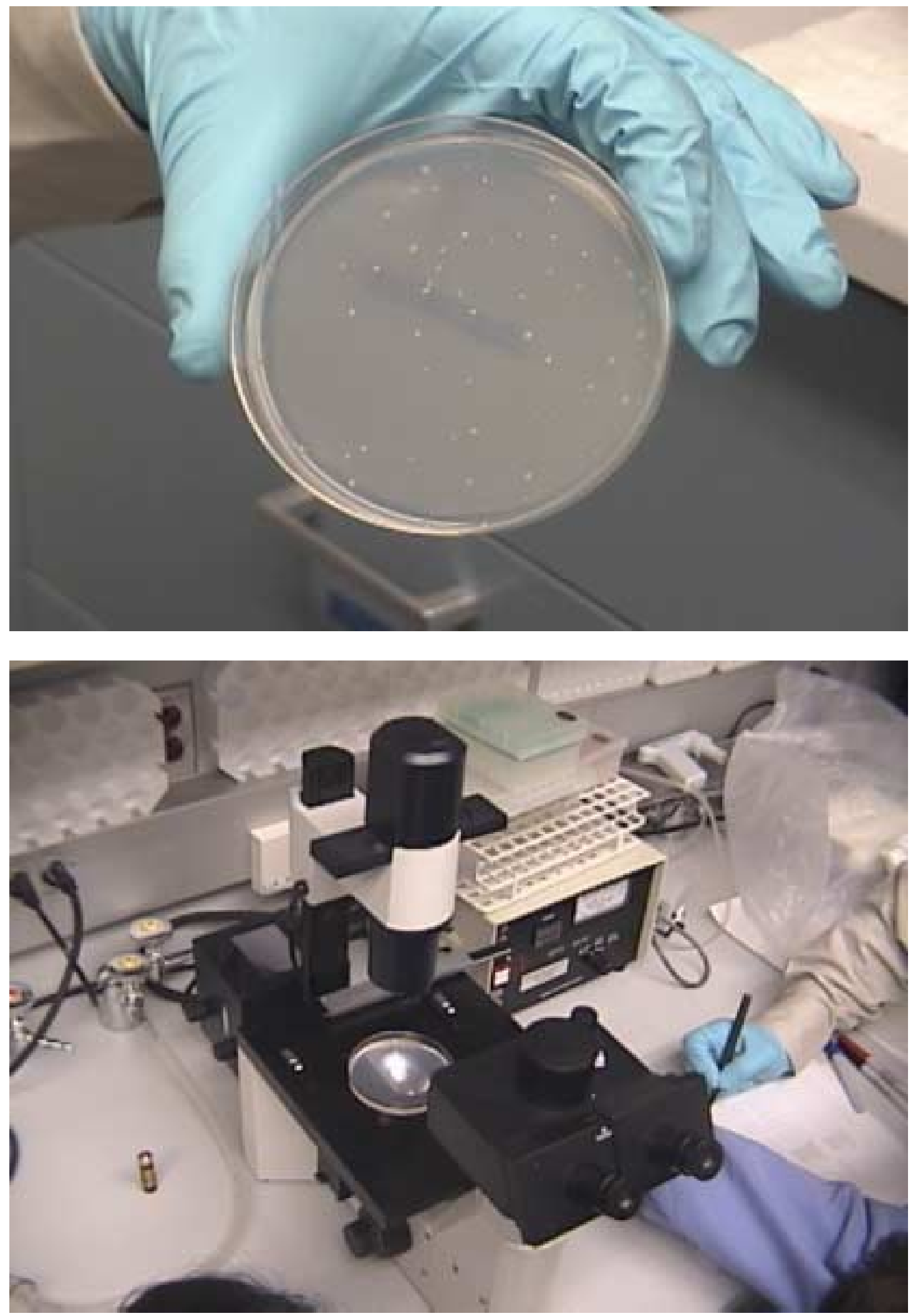

Figure 6. Example of revertant colonies and inverted microscope. 


\section{STATISTICAL TREATMENT}

Dunnett's Method was used to compare the sample means with the negative control mean $($ Alpha $=0.05)$. An ANOVA was used to compare the tester strains TA98 and TA100.

\section{EQUIPMENT AND MATERIALS}

\section{LARGE EQUIPMENT}

1 SterilGARD III Advance laminar flow hood (The Baker Company, Samford, Maine)

1 Automatic colony counter (Artek Counter, Model 880)

1 Bio Freezer $\left(-80^{\circ} \mathrm{C}\right)$

1 Water bath (Precision Scientific, Model 82, Chicago, Il.)

1 Forma Scientific stationary incubator

1 Inverted microscope (Leica DMIL, Leitz Wetzlar, Germany)

\section{SMALL EQUIPMENT}

Adjustable micropipettes

12 4.0ml glass vials (for test samples) with Teflon lined caps

232 Disposable glass culture tubes (13mm x 100mm)

Latex surgeon's gloves

6 Plastic cryotubes for storage of S-9

1 Vortexer (Vortex Genie2)

6 Test tube racks

1 Electronic balance (American Scientific Products)

1Brinkmann dispensette 
1 package AHPlus sealer (Dentsply USA, York, PA)

1 package RSA Roekoseal Automix sealer (Roeko USA, Monrovia, CA)

1 Mixing pad

1 Spatula

1 Mortar and pestle

232 Plastic petri plates (Falcon \#1029)

1 Humidified chamber (100\% humidity)

Salmonella typhimurium tester strains TA98 and TA100 (Bruce Ames Laboratory, Berkely, CA) 


\section{CHAPTER IV}

\section{RESULTS AND DISCUSSION}

\section{RESULTS}

MUTAGENICITY DMSO eluates of freshly mixed and 24h set RSA Roekoseal Automix were nonmutagenic to tester strains TA98 and TA100 in the presence and absence of S9. However, .312mg/plate of freshly mixed RSA Roekoseal Automix without S9 mix displayed a significantly higher number of revertants as compared to the negative control in tester strain TA100. DMSO eluates of freshly mixed and $24 \mathrm{~h}$ set AHPlus with and without S9 mix were mutagenic to tester strain TA98 at a dose of 10mg/plate. DMSO eluates of freshly mixed and 24h set AHPlus with and without S9 were mutagenic to tester strain TA100 in a dose related manner. Appendix B displays statistical analysis of each sample by means of Dunnett's Method for comparing sample means.

The effectiveness of the S9 liver fraction was verified by the positive control 2AA. 2AA is only mutagenic to tester strains TA98 and TA100 in the presence of S9. This was demonstrated by a $10-30$ fold increase in the number of revertants with S9 as compared to without S9.

An analysis of variance comparing tester strains TA98 and TA100 demonstrated that TA100 has a statistically significant greater amount of revertants colonies per plate 
than TA98. Thus verifying that the number of revertant colonies produced per plate was a characteristic of the tester strain.

BACKGROUND LAWN TOXICITY AHPlus after setting 24 hours at a concentration of $10 \mathrm{mg} /$ plate was toxic to the TA100 tester strain (Figure 8). Freshly mixed AHPlus showed no toxic effects at any concentration towards either TA98 or TA100. Freshly mixed and 24 hour set RSA Roekoseal Automix showed no toxic effects at any concentration towards either TA98 or TA100.

\section{DISCUSSION}

In the present study, the mutagenicity of the new polydimethylsiloxane based root canal sealing cement, RSA Roekoseal automix, was tested using the Salmonellal microsome gene mutation assay. Resin based root canal sealing cement, AHPlus, was also tested in the same manner. The two tester strains, S. typhimurium TA98 and TA100, were employed to detect the induction of frameshift and base-pair mutations. The mixed samples of RSA Roekoseal Automix and AHPlus, which were set for $24 \mathrm{~h}$, were first chopped up (RSA Roekoseal Automix) and powdered (AHPlus) and then eluted in an aqueous solvent. Therefore, the surface of the material is large in vitro, compared to the amount of material that could extrude through the apical foramen to the periapical tissues in vivo. These differences should be considered before these results can be extrapolated into a clinical situation.

The mixed RSA Roekoseal Automix was nonmutagenic in this test under extreme experimental conditions. Only freshly mixed RSA Roekoseal at the lowest tested concentration showed increased numbers of revertant colonies when compared to the 
negative control. This increase may have been attributed to an error in the amount of histidine added to the top agar. Maron and Ames (1983) pointed out that the number of revertants that arise in $48 \mathrm{~h}$ incubation is dependant on the final number of auxotrophs on the plate and that number is a function of the histidine concentration. Therefore, a slight increase in histidine, due to human error, may have caused an increase in the number of revertant colonies (14).

The findings that DMSO eluates of RSA Roekoseal Automix are nonmutagenic provide evidence that the unpolymerized and polymerized ingredients are also nonmutagenic in the test. Moreover, these findings also suggest that the unpolymerized and polymerized ingredients of RSA Roekoseal Automix are nontoxic.

The mixed AHPlus was directly mutagenic in this test under extreme experimental conditions, and the severity of this effect depended on the setting period after mixing. Both freshly mixed and $24 \mathrm{~h}$ set AHPlus induced a dose related increase in the number of mutant numbers in strain TA100. The findings that AHPlus was more mutagenic to tester strain TA100 indicate that the material induces more base pair substitutions. The direct mutagenicity of DMSO eluates of freshly mixed AHPlus decreased in strain TA100 at higher concentrations in the presence of a metabolically active microsomal fraction from rat liver (S9). Since DMSO eluates seemed to be more toxic in the presence of S9, the mutagenic substance might have been converted to a toxic component or a different substance was activated to a toxic metabolite. Therefore, the decrease in mutagenicity may have been a result of an increase in toxicity.

These findings provide evidence that one, or more, ingredients, which are produced in the polymerized and unpolymerized material, elicit the mutagenic effect of 
DMSO eluates. It is most likely that the epoxy resin is the mutagenic ingredient in AHPlus because of the very similar effects of this material compared to those elicited by DMSO eluates of the mixed AH26 in a previous investigation. Evidence was provided that the epoxy resin, bisphenol A diglycidalether, is the mutagenic compound of AH26 (29). Also, the findings of this experiment concerning the mutagenicity of AHPlus are similar to those discovered by Schweikl et al. in 1998 (22).

Further in vitro and in vivo studies are needed to determine the clinical safety of AHPlus root canal sealers. Also, further investigation is necessary in order to determine whether the mutagenicity of AHPlus could result in bacterial resistance. 


\section{CHAPTER V}

\section{SUMMARY AND CONCLUSION}

\section{SUMMARY}

The mutagenic activity of the root canal sealing cement, RSA Roekoseal Automix, was tested in the bacterial gene mutation assay (Ames test). Root canal sealing cement AHPlus was also tested and used as a comparison. Both materials were mixed according to the manufacturer's instruction and tested immediately after mixing and after a setting time of $24 \mathrm{~h}$ at $37^{\circ} \mathrm{C}$ in a $100 \%$ humidified chamber. The set material was powdered and both the freshly mixed and powdered material were eluted in dimethyl sulfoxide (DMSO) for $24 \mathrm{~h}$ at $37^{\circ} \mathrm{C}$. Aliquots of serially diluted eluates were then used in the standard plate incorporation assay. The Salmonella typhimurium tester strains TA98 and TA100 were used to detect the induction of frameshift mutations and base pair substitutions both in the presence and absence of a metabolically active microsomal fraction from rat liver (S9 fraction). No mutagenic or toxic effects were found with DMSO eluates of freshly mixed or $24 \mathrm{~h}$ set RSA Roekoseal Automix. However, DMSO eluates of the freshly mixed and $24 \mathrm{~h}$ set AHPlus was mutagenic in tester strain TA98 at higher concentrations. Eluates of the freshly mixed AHPlus were mutagenic in tester strain TA 100 in a dose related manner in the absence of metabolically active S9 fraction. Eluates of the AHPlus material set for $24 \mathrm{~h}$ were mutagenic in the tester strain TA100 in a 
dose related manner in the presence and absence of S9. The AHPlus set material was more toxic than the freshly mixed material at higher concentrations.

\section{CONCLUSION}

In conclusion, RSA Roekoseal Automix is nonmutagenic and nontoxic in $\underline{S}$. typhimurium TA98 and TA100. Also, both freshly mixed and 24h set RSA Roekoseal Automix is less mutagenic than AHPlus in TA98 and TA100 with and without the presence of S9 mix. Therefore, RSA Roekoseal Automix is a safe root canal sealing material and should be used freely in clinical situations. On the other hand, caution should be advised before using AHPlus root canal sealer in a clinical situation. Further investigation is needed before AHPlus can be safely applied. 


\section{REFERENCES}

1. Pumarola J, et al. "Antimicrobial activity of seven root canal sealers." Oral Surg Oral Med Oral Pathol 74 (1992): 216-220.

2. DeDeur QD. "Frequency, location, and direction of the lateral, secondary, and accessory canals.” J Endodon 1 (1975): 361-366.

3. Antrim DD. "Evaluation of the cytotoxicity of root canal sealing agents on tissue culture cells in vitro: Grossman's sealer, N2 (permanent), Rickert's sealer, and cavit." J Endodon 2 (1976): 111-116.

4. Mittal M, Chandra S, and Chandra S. "Comparative tissue toxicity evaluation of four endodontic sealers.” J Endodon 21 (1995): 622-624.

5. Hong $\mathrm{YC}$, et al "The periapical tissue reaction to a calcium phosphate cement in the teeth of monkeys." J Biomed Mater Res 25 (1991): 485-498.

6. Kolokurris I, et al. "Experimental study of the biocompatibility of a new glass ionomer root canal sealer (Ketac-Endo).” J Endodon 22 (1996): 395-398.

7. Pascon EA, et al. "Tissue reaction to endodontic materials: methods, criteria, assessment, and observations. Oral Surg Oral Med Oral Pathol 72 (1991): 222-237.

8. Spangberg LSW, Barbosa SV, and Lavigne GD. "AH26 releases formaldehyde. J Endodon 19 (1993): 596-598.

9. Guertsen W, and Leyhausen G. "Biological aspects of root canal filling materialshistocompatibility, cytotoxicity, and mutagenicity." Clin Oral Invest. 1(1997): 5-11.

10. Ersev H, et al. "Cytotoxic and mutagenic potencies of various root canal filling materials in eukaryotic and prokaryotic cells in vitro." J. Endodon 1998 (In Press).

11. Orstavik D, and Hongslo JK. "Mutagenicity of endodontic sealers. Biomaterials 6 (1985): 129-132.

12. Canter DA, et al. "Comparative mutagenicity of aliphatic epoxides in Salmonella." Mutat Res 172 (1986): 105-138.

13. Schweikl H, Schmalz G, and Federlin M. "Mutagenicity of the root canal sealer 
AHPlus in the Ames Test." Clin Oral Inves 2 (1998): 125-129.

14. Maron DM, and Ames BN. "Revised method for the salmonella mutagenicity test." Mutat Res 113 (1983): 173-215.

15. Stea S, et al. "Mutagenic potential of root canal sealers; evaluation through Ames testing." J. Biomed Mut Res. 28 (1994): 319-328.

16. Chaudhry R, et al. "Anaerobic Flora in endodontic infections.” Indian J Med Res 105 (1997): 262-265.

17. Baumgartner JC, et al. "Association of black pigmented bacteria with endodontic infections.” J Endodon. 25(6) (1999): 413-415.

18. Grossman L. “Antimicrobial effect of root canal cements.” J Endodon; 6 (1980): 594597.

19. Fuss Z, Weiss EI, and Halvah M. "Antibacterial activity of calcium hydroxide containing endodontic sealers on Enterococcus faecalis in vitro.” Int Endod J 30(6) (1997): 397-402.

20. Briseno BM, and Willershausen B. "Root canal sealer cytotoxicity on human gingival fibroblasts. Part I: Zinc Oxide-Eugenol based sealers.” J Endodon Aug 1990

21. Osorio RM, et al. "Cytotoxicity of endodontic materials.” J Endodon. 24(1998): 91-96.

22. Schweikl H, Schmalz G, and Federlin M. "Mutagenicity of the root canal sealer AHPlus in the Ames test." Clin Oral Invest. 2 (1998): 125-129.

23. Tronstadt L, and Wennberg A. "In vitro assessment of the toxicity of filling materials" Int Endodon J. 13 (1980): 131-138.

24. Wennberg A. "Biological evaluation of root canal sealers using in vitro and in vivo models." J Edodon 6 (1980):784-787.

25. Leyhausen G, et al. "The geotaxis potential of composite components (in German)." Dutch Zahnarztl 1995; 50:134-136.

26. Heil J, et al. “Genotoxicity of dental materials.” Mutat Res. 368 (1996):181-194.

27. Geurtsen W, and Leyhausen G. "Biological aspects of root canal filling materialshistocompatability, cytotoxicity, and mutagenicity." Clin Oral Invest. 1(1997): 5-11.

28. Oda Y, et al. "Evaluation of the new system (umu-test) for the detection of 
environmental mutagens and carcinogens.” Mutat Res. 147 (1985): 219-229.

29. Orstavik D, and Hongslo JK. "Mutagenicity of endodontic sealers." Biomaterials 6(2) (1985): 129-132.

30. Leyhausen G, et al. "Genotoxicity and cytotoxicity of the epoxy resin-based root canal sealer AH Plus.” J Endodon. 25(2) (1999): 109-113.

31. Schweikl H, et al. "Mutagenicity of AH26 in an in vitro mammalian cell mutation assay.” J Endodon. 21(8) (1995): 407-410.

32. Ersev H, et al. "Cytotoxic and mutagenic potencies of various root canal filling materials in eukaryotic and prokaryotic cells in vitro." J Endodon. 25 (1999):359-363.

33. American National Standards Institute/American Dental Association Documents No. 41 for recommended standard practices for biological evaluation of dental Materials. J Amer Dent Assoc. 99 (1979): 697-698.

34. Recommended standard practices for biological evaluation of dental materials. Int Dent J. 30 (1980): 140-188.

35. Auerbach M. "Antibiotics vs. instrumentation in endodontics: A reply." New York State Dental Journal. 19 (1953) 1953: 225-228.

36. Grossman L. "Antibiotics vs. instrumentation in endodontics: A reply." New York State Dental Journal. 19 (1953): 409-412.

37. Estrala $\mathrm{C}$, et al "In vitro determination of direct antimicrobial affect of $\mathrm{CaOH}$." $\mathrm{J}$ Endodon. 24 (1998): 15-17.

38. Sunqvist G. "Taxonomy, ecology and pathogenicity of the root canal flora." Oral Surg; 78 (1994): 522-530.

39. Haapasalo M, Ranta H, and Ranta K. "Facultative gram-negative enteric rods in periapical infections." Acta Odontologica Scandinavica. 41 (1983): 19-21.

40. Akpata ES, and Blechman H. "Bacterial invasion on pulpal dentin wall in vitro". $\underline{\mathbf{J}}$ Dent Res. 61 (1982): 435-438.

41 McCann J., et al "Detection of carcinogens as mutagens in the Salmonella/. microsome test: Assay of 300 chemicals". Proc. Natl. Acad. Sci(USA). 72 (1975a): 5135-5139.

42. Ames B.N., and McCann J. Validation of the Salmonella test: A reply to Rinkus and Legator. Cancer Research 1981; 41:4192-4196. 
43. Ames B.N. "The detection of chemical mutagens with enteric bacteria: A. Hollaender (Ed.). Chemical Mutagens, Principles and Methods for Their Detection" Plenum, New York, 1(1971): 267-282.

44. Barnes W., Tuley E., and Eisenstadt E. "Base-sequence analysis of His+ revertants of the hisG46 missense mutation in Salmonella typhimurium, Environ. Mutagen, 4 (1982): 297.

45. Yahagi, T., et al. "Mutagenicity of carcinogenic azo dyes and their derivatives " Cancer Lett. 1 (1975): 91-96.

46. Belser W.L., Jr., et al. "A standardized procedure for quantification of the Ames Salmonella/Mammalian-microsome mutagenicity. Environ Mutagen., 3 (1981): 123-139. 
APPENDIX A

\section{Raw Data Forms}




\section{Ames Test --- Raw Data Sheets}

Test Date: 3-27-2001

AHPlus after mixing

\begin{tabular}{|l|l|l|l|l|l|l|l|l|l|}
\hline Tester & \multirow{2}{*}{$\begin{array}{l}\text { Concentration } \\
\text { Mg/plate }\end{array}$} & \multicolumn{4}{c|}{$\begin{array}{c}\text { - S9 } \\
\text { Revertants per plate }\end{array}$} & \multicolumn{5}{c|}{ Revertants per plate } \\
\hline & & 1 & 2 & 3 & Mean & 1 & 2 & 3 & Mean \\
\hline TA98 & $10 \mathrm{mg} / .1 \mathrm{ml}$ & & & & & & & & \\
\hline & $10 \mathrm{mg} / .1 \mathrm{ml}$ & & & & & & & & \\
\hline & $5 \mathrm{mg} / .1 \mathrm{ml}$ & & & & & & & & \\
\hline & $5 \mathrm{mg} / .1 \mathrm{ml}$ & & & & & & & & \\
\hline & $2.5 \mathrm{mg} / .1 \mathrm{ml}$ & & & & & & & & \\
\hline & $2.5 \mathrm{mg} / .1 \mathrm{ml}$ & & & & & & & & \\
\hline & $1.25 \mathrm{mg} / .1 \mathrm{ml}$ & & & & & & & & \\
\hline & $1.25 \mathrm{mg} / .1 \mathrm{ml}$ & & & & & & & & \\
\hline & $.625 \mathrm{mg} / .1 \mathrm{ml}$ & & & & & & & & \\
\hline & $.625 \mathrm{mg} / .1 \mathrm{ml}$ & & & & & & & & \\
\hline & $.312 \mathrm{mg} / .1 \mathrm{ml}$ & & & & & & & & \\
\hline & $.312 \mathrm{mg} / .1 \mathrm{ml}$ & & & & & & & & \\
\hline
\end{tabular}

AHPlus after mixing

\begin{tabular}{|c|c|c|c|c|c|c|c|c|c|}
\hline \multirow[t]{2}{*}{ tester } & \multirow[t]{2}{*}{$\begin{array}{l}\text { Concentration } \\
\mathrm{Mg} / \text { plate }\end{array}$} & \multicolumn{4}{|c|}{$\begin{array}{c}- \text { S9 } \\
\text { Revertants per plate }\end{array}$} & \multicolumn{4}{|c|}{$\begin{array}{c}+\mathrm{S} 9 \\
\text { Revertants per plate }\end{array}$} \\
\hline & & 1 & 2 & 3 & mean & 1 & 2 & 3 & mean \\
\hline TA100 & $10 \mathrm{mg} / .1 \mathrm{ml}$ & & & & & & & & \\
\hline & $10 \mathrm{mg} / .1 \mathrm{ml}$ & & & & & & & & \\
\hline & $5 \mathrm{mg} / .1 \mathrm{ml}$ & & & & & & & & \\
\hline & $5 \mathrm{mg} / .1 \mathrm{ml}$ & & & & & & & & \\
\hline & $2.5 \mathrm{mg} / .1 \mathrm{ml}$ & & & & & & & & \\
\hline & $2.5 \mathrm{mg} / .1 \mathrm{ml}$ & & & & & & & & \\
\hline & $1.25 \mathrm{mg} / .1 \mathrm{ml}$ & & & & & & & & \\
\hline & $1.25 \mathrm{mg} / .1 \mathrm{ml}$ & & & & & & & & \\
\hline & $.625 \mathrm{mg} / .1 \mathrm{ml}$ & & & & & & & & \\
\hline & $.625 \mathrm{mg} / .1 \mathrm{ml}$ & & & & & & & & \\
\hline & $.312 \mathrm{mg} / .1 \mathrm{ml}$ & & & & & & & & \\
\hline & $.312 \mathrm{mg} / .1 \mathrm{ml}$ & & & & & & & & \\
\hline
\end{tabular}

Table 3. Mutagenicity of dimethyl sulfoxide (DMSO) eluates of freshly mixed AHPlus. One gram of freshly mixed AHPlus was eluted in $10 \mathrm{ml}$ DMSO for $24 \mathrm{~h}$ and aliquots of the original eluate were tested with Samonella typhimurium strains TA98 and TA100 in the presence and in the absence of microsomal fraction from rat liver (S9). 
Test Date: 3-27-2001

AHPlus after setting $24 \mathrm{~h}$

\begin{tabular}{|c|c|c|c|c|c|c|c|c|c|}
\hline \multirow[t]{2}{*}{ tester } & \multirow[t]{2}{*}{$\begin{array}{l}\text { Concentration } \\
\mathrm{Mg} / \text { plate }\end{array}$} & \multicolumn{4}{|c|}{$\begin{array}{c}- \text { S9 } \\
\text { Revertants per plate }\end{array}$} & \multicolumn{4}{|c|}{$\begin{array}{l}+\mathrm{S} 9 \\
\text { Revertants per plate }\end{array}$} \\
\hline & & 1 & 2 & 3 & mean & 1 & 2 & 3 & mean \\
\hline \multirow[t]{12}{*}{ TA98 } & $10 \mathrm{mg} / .1 \mathrm{ml}$ & & & & & & & & \\
\hline & $10 \mathrm{mg} / .1 \mathrm{ml}$ & & & & & & & & \\
\hline & $5 \mathrm{mg} / .1 \mathrm{ml}$ & & & & & & & & \\
\hline & $5 \mathrm{mg} / .1 \mathrm{ml}$ & & & & & & & & \\
\hline & $2.5 \mathrm{mg} / .1 \mathrm{ml}$ & & & & & & & & \\
\hline & $2.5 \mathrm{mg} / .1 \mathrm{ml}$ & & & & & & & & \\
\hline & $1.25 \mathrm{mg} / .1 \mathrm{ml}$ & & & & & & & & \\
\hline & $1.25 \mathrm{mg} / .1 \mathrm{ml}$ & & & & & & & & \\
\hline & $.625 \mathrm{mg} / .1 \mathrm{ml}$ & & & & & & & & \\
\hline & $.625 \mathrm{mg} / .1 \mathrm{ml}$ & & & & & & & & \\
\hline & $.312 \mathrm{mg} / .1 \mathrm{ml}$ & & & & & & & & \\
\hline & $.312 \mathrm{mg} / .1 \mathrm{ml}$ & & & & & & & & \\
\hline
\end{tabular}

AHPlus after setting 24h

\begin{tabular}{|c|c|c|c|c|c|c|c|c|c|}
\hline \multirow[t]{2}{*}{ tester } & \multirow[t]{2}{*}{$\begin{array}{l}\text { Concentration } \\
\mathrm{Mg} / \text { plate }\end{array}$} & \multicolumn{4}{|c|}{$\begin{array}{c}- \text { S9 } \\
\text { Revertants per plate }\end{array}$} & \multicolumn{4}{|c|}{$\begin{array}{c}+\mathrm{S} 9 \\
\text { Revertants per plate }\end{array}$} \\
\hline & & 1 & 2 & 3 & Mean & 1 & 2 & 3 & Mean \\
\hline TA100 & $10 \mathrm{mg} / .1 \mathrm{ml}$ & & & & & & & & \\
\hline & $10 \mathrm{mg} / .1 \mathrm{ml}$ & & & & & & & & \\
\hline & $5 \mathrm{mg} / .1 \mathrm{ml}$ & & & & & & & & \\
\hline & $5 \mathrm{mg} / .1 \mathrm{ml}$ & & & & & & & & \\
\hline & $2.5 \mathrm{mg} / .1 \mathrm{ml}$ & & & & & & & & \\
\hline & $2.5 \mathrm{mg} / .1 \mathrm{ml}$ & & & & & & & & \\
\hline & $1.25 \mathrm{mg} / .1 \mathrm{ml}$ & & & & & & & & \\
\hline & $1.25 \mathrm{mg} / .1 \mathrm{ml}$ & & & & & & & & \\
\hline & $.625 \mathrm{mg} / .1 \mathrm{ml}$ & & & & & & & & \\
\hline & $.625 \mathrm{mg} / .1 \mathrm{ml}$ & & & & & & & & \\
\hline & $.312 \mathrm{mg} / .1 \mathrm{ml}$ & & & & & & & & \\
\hline & $.312 \mathrm{mg} / .1 \mathrm{ml}$ & & & & & & & & \\
\hline
\end{tabular}

Table 4. Mutagenicity of DMSO eluates of mixed AHPlus after setting for $24 \mathrm{~h}$. One gram of mixed AHPlus that was set for $24 \mathrm{~h}$ was then eluted in $10 \mathrm{ml}$ DMSO for $24 \mathrm{~h}$. Aliquots of the original eluate were tested with Salmonella typhimurium strains TA98 and TA100 in the presence and in the absence of microsomal fraction from liver rat (S9). 
Test Date: 3-27-2001

RSA Roekoseal after mixing

\begin{tabular}{|c|c|c|c|c|c|c|c|c|c|}
\hline \multirow[t]{2}{*}{ tester } & \multirow[t]{2}{*}{$\begin{array}{l}\text { Concentration } \\
\mathrm{Mg} / \text { plate }\end{array}$} & \multicolumn{4}{|c|}{$\begin{array}{c}- \text { S9 } \\
\text { Revertants per plate }\end{array}$} & \multicolumn{4}{|c|}{$\begin{array}{c}+\mathrm{S} 9 \\
\text { Revertants per plate }\end{array}$} \\
\hline & & 1 & 2 & 3 & Mean & 1 & 2 & 3 & Mean \\
\hline \multirow[t]{12}{*}{ TA98 } & $10 \mathrm{mg} / .1 \mathrm{ml}$ & & & & & & & & \\
\hline & $10 \mathrm{mg} / .1 \mathrm{ml}$ & & & & & & & & \\
\hline & $5 \mathrm{mg} / .1 \mathrm{ml}$ & & & & & & & & \\
\hline & $5 \mathrm{mg} / .1 \mathrm{ml}$ & & & & & & & & \\
\hline & $2.5 \mathrm{mg} / .1 \mathrm{ml}$ & & & & & & & & \\
\hline & $2.5 \mathrm{mg} / .1 \mathrm{ml}$ & & & & & & & & \\
\hline & $1.25 \mathrm{mg} / .1 \mathrm{ml}$ & & & & & & & & \\
\hline & $1.25 \mathrm{mg} / .1 \mathrm{ml}$ & & & & & & & & \\
\hline & $.625 \mathrm{mg} / .1 \mathrm{ml}$ & & & & & & & & \\
\hline & $.625 \mathrm{mg} / .1 \mathrm{ml}$ & & & & & & & & \\
\hline & $.312 \mathrm{mg} / .1 \mathrm{ml}$ & & & & & & & & \\
\hline & $.312 \mathrm{mg} / .1 \mathrm{ml}$ & & & & & & & & \\
\hline
\end{tabular}

RSA Roekoseal after mixing

\begin{tabular}{|c|c|c|c|c|c|c|c|c|c|}
\hline \multirow[t]{2}{*}{ tester } & \multirow[t]{2}{*}{$\begin{array}{l}\text { Concentration } \\
\mathrm{Mg} / \text { plate }\end{array}$} & \multicolumn{4}{|c|}{$\begin{array}{c}- \text { S9 } \\
\text { Revertants per plate }\end{array}$} & \multicolumn{4}{|c|}{$\begin{array}{c}+\mathrm{S} 9 \\
\text { Revertants per plate }\end{array}$} \\
\hline & & 1 & 2 & 3 & Mean & 1 & 2 & 3 & Mean \\
\hline \multirow[t]{12}{*}{ TA100 } & $10 \mathrm{mg} / .1 \mathrm{ml}$ & & & & & & & & \\
\hline & $10 \mathrm{mg} / .1 \mathrm{ml}$ & & & & & & & & \\
\hline & $5 \mathrm{mg} / .1 \mathrm{ml}$ & & & & & & & & \\
\hline & $5 \mathrm{mg} / .1 \mathrm{ml}$ & & & & & & & & \\
\hline & $2.5 \mathrm{mg} / .1 \mathrm{ml}$ & & & & & & & & \\
\hline & $2.5 \mathrm{mg} / .1 \mathrm{ml}$ & & & & & & & & \\
\hline & $1.25 \mathrm{mg} / .1 \mathrm{ml}$ & & & & & & & & \\
\hline & $1.25 \mathrm{mg} / .1 \mathrm{ml}$ & & & & & & & & \\
\hline & $.625 \mathrm{mg} / .1 \mathrm{ml}$ & & & & & & & & \\
\hline & $.625 \mathrm{mg} / .1 \mathrm{ml}$ & & & & & & & & \\
\hline & $.312 \mathrm{mg} / .1 \mathrm{ml}$ & & & & & & & & \\
\hline & $.312 \mathrm{mg} / .1 \mathrm{ml}$ & & & & & & & & \\
\hline
\end{tabular}

Table 5. Mutagenicity of dimethyl sulfoxide (DMSO) eluates of freshly mixed RSA Roekoseal Automix. One gram of freshly mixed RSA Roekoseal Automix was eluted in $10 \mathrm{ml}$ DMSO for $24 \mathrm{~h}$ and aliquots of the original eluate were tested with Samonella typhimurium strains TA98 and TA100 in the presence and in the absence of microsomal fraction from rat liver (S9). 
Test Date: 3-27-2001

RSA Roekoseal after setting $24 \mathrm{~h}$

\begin{tabular}{|c|c|c|c|c|c|c|c|c|c|}
\hline \multirow[t]{2}{*}{ tester } & \multirow[t]{2}{*}{$\begin{array}{l}\text { Concentration } \\
\mathrm{Mg} / \text { plate }\end{array}$} & \multicolumn{4}{|c|}{$\begin{array}{c}\text { - S9 } \\
\text { Revertants per plate }\end{array}$} & \multicolumn{4}{|c|}{$\begin{array}{c}\text { S9 } \\
\text { Revertants per plate }\end{array}$} \\
\hline & & 1 & 2 & 3 & Mean & 1 & 2 & 3 & Mean \\
\hline \multirow[t]{12}{*}{ TA98 } & $10 \mathrm{mg} / .1 \mathrm{ml}$ & & & & & & & & \\
\hline & $10 \mathrm{mg} / .1 \mathrm{ml}$ & & & & & & & & \\
\hline & $5 \mathrm{mg} / .1 \mathrm{ml}$ & & & & & & & & \\
\hline & $5 \mathrm{mg} / .1 \mathrm{ml}$ & & & & & & & & \\
\hline & $2.5 \mathrm{mg} / .1 \mathrm{ml}$ & & & & & & & & \\
\hline & $2.5 \mathrm{mg} / .1 \mathrm{ml}$ & & & & & & & & \\
\hline & $1.25 \mathrm{mg} / .1 \mathrm{ml}$ & & & & & & & & \\
\hline & $1.25 \mathrm{mg} / .1 \mathrm{ml}$ & & & & & & & & \\
\hline & $.625 \mathrm{mg} / .1 \mathrm{ml}$ & & & & & & & & \\
\hline & $.625 \mathrm{mg} / .1 \mathrm{ml}$ & & & & & & & & \\
\hline & $.312 \mathrm{mg} / .1 \mathrm{ml}$ & & & & & & & & \\
\hline & $.312 \mathrm{mg} / .1 \mathrm{ml}$ & & & & & & & & \\
\hline
\end{tabular}

RSA Roekoseal after setting $24 \mathrm{~h}$

\begin{tabular}{|c|c|c|c|c|c|c|c|c|c|}
\hline \multirow[t]{2}{*}{ tester } & \multirow[t]{2}{*}{$\begin{array}{l}\text { Concentration } \\
\mathrm{Mg} / \text { plate }\end{array}$} & \multicolumn{4}{|c|}{$\begin{array}{c}- \text { S9 } \\
\text { Revertants per plate }\end{array}$} & \multicolumn{4}{|c|}{$\begin{array}{c}+\mathrm{S} 9 \\
\text { Revertants per plate }\end{array}$} \\
\hline & & 1 & 2 & 3 & Mean & 1 & 2 & 3 & Mean \\
\hline TA100 & $10 \mathrm{mg} / .1 \mathrm{ml}$ & & & & & & & & \\
\hline & $10 \mathrm{mg} / .1 \mathrm{ml}$ & & & & & & & & \\
\hline & $5 \mathrm{mg} / .1 \mathrm{ml}$ & & & & & & & & \\
\hline & $5 \mathrm{mg} / .1 \mathrm{ml}$ & & & & & & & & \\
\hline & $2.5 \mathrm{mg} / .1 \mathrm{ml}$ & & & & & & & & \\
\hline & $2.5 \mathrm{mg} / .1 \mathrm{ml}$ & & & & & & & & \\
\hline & $1.25 \mathrm{mg} / .1 \mathrm{ml}$ & & & & & & & & \\
\hline & $1.25 \mathrm{mg} / .1 \mathrm{ml}$ & & & & & & & & \\
\hline & $.625 \mathrm{mg} / .1 \mathrm{ml}$ & & & & & & & & \\
\hline & $.625 \mathrm{mg} / .1 \mathrm{ml}$ & & & & & & & & \\
\hline & $.312 \mathrm{mg} / .1 \mathrm{ml}$ & & & & & & & & \\
\hline & $.312 \mathrm{mg} / .1 \mathrm{ml}$ & & & & & & & & \\
\hline
\end{tabular}

Table 6. Mutagenicity of DMSO eluates of mixed RSA Roekoseal Automix after setting for $24 \mathrm{~h}$. One gram of mixed RSA Roekoseal Automix that was set for $24 \mathrm{~h}$ was then eluted in $10 \mathrm{ml}$ DMSO for $24 \mathrm{~h}$. Aliquots of the original eluate were tested with Salmonella typhimurium strains TA98 and TA100 in the presence and in the absence of microsomal fraction from liver rat (S9). 
Test Date: 3-27-2001

Negative control: DMSO

\begin{tabular}{|l|l|l|l|l|l|l|l|l|l|}
\hline \multirow{2}{*}{ tester } & Concentration & \multicolumn{4}{|c|}{$\begin{array}{c}\text { - S9 } \\
\text { ul/plate }\end{array}$} & \multicolumn{3}{c|}{ Revertants per plate } & \multicolumn{5}{c|}{ Revertants per plate } \\
\cline { 3 - 10 } & & 1 & 2 & 3 & Mean & 1 & 2 & 3 & Mean \\
\hline TA98 & $10 \mathrm{ul} / .1 \mathrm{ml}$ & & & & & & & & \\
\hline & $10 \mathrm{ul} / .1 \mathrm{ml}$ & & & & & & & & \\
\hline TA100 & $10 \mathrm{ul} / .1 \mathrm{ml}$ & & & & & & & & \\
\hline & $10 \mathrm{ul} / .1 \mathrm{ml}$ & & & & & & & & \\
\hline
\end{tabular}

Table 7. Negative control DMSO. Spontaneous revertants per plate

Positive control: 2AA

\begin{tabular}{|c|c|c|c|c|c|c|c|c|c|}
\hline \multirow[t]{2}{*}{ tester } & \multirow[t]{2}{*}{$\begin{array}{l}\text { Concentration } \\
\text { ul/plate }\end{array}$} & \multicolumn{4}{|c|}{$\begin{array}{c}- \text { S9 } \\
\text { Revertants per plate }\end{array}$} & \multicolumn{4}{|c|}{$\begin{array}{c}+\mathrm{S} 9 \\
\text { Revertants per plate }\end{array}$} \\
\hline & & 1 & 2 & 3 & Mean & 1 & 2 & 3 & Mean \\
\hline TA 98 & 2.5ul/plate & & & & & & & & \\
\hline & 2.5ul/plate & & & & & & & & \\
\hline TA100 & $2.5 \mathrm{ul} / \mathrm{plate}$ & & & & & & & & \\
\hline & 2.5ul/plate & & & & & & & & \\
\hline & 5.0ul/plate & & & & & & & & \\
\hline & 5.0ul/plate & & & & & & & & \\
\hline
\end{tabular}

Table 8. Positive control 2AA. Mutagenicity of a known mutagenic chemical.

Positive control: 1-NP

\begin{tabular}{|l|l|l|l|l|l|l|l|l|l|}
\hline tester & Concentration & \multicolumn{4}{|c|}{ - S9 } & \multicolumn{5}{c|}{+ S9 } \\
& & & \multicolumn{3}{c|}{ Revertants per plate } & \multicolumn{5}{c|}{ Revertants per plate } \\
\cline { 3 - 10 } & & 1 & 2 & 3 & Mean & 1 & 2 & 3 & Mean \\
\hline TA 98 & $1.0 \mathrm{ul} /$ plate & & & & & & & & \\
\hline & $1.0 \mathrm{ul} /$ plate & & & & & & & & \\
\hline TA100 & $2.5 \mathrm{ul} /$ plate & & & & & & & & \\
\hline & $2.5 \mathrm{ul} /$ plate & & & & & & & & \\
\hline & $5.0 \mathrm{ul} /$ plate & & & & & & & & \\
\hline & $5.0 \mathrm{ul} /$ plate & & & & & & & & \\
\hline
\end{tabular}

Table 9. Positive control 1-NP. Mutagenicity of a known mutagenic chemical. 
Ames test background lawn condition

Test date: $3-30-2001$

\begin{tabular}{|c|c|c|c|c|c|c|c|c|c|}
\hline \multirow[t]{3}{*}{ Sample } & \multirow[t]{3}{*}{ Concentration } & \multicolumn{4}{|c|}{ TA98 } & \multicolumn{4}{|c|}{ TA100 } \\
\hline & & \multicolumn{2}{|c|}{-S9 } & \multicolumn{2}{|c|}{$+\mathrm{S} 9$} & \multicolumn{2}{|c|}{-S9 } & \multicolumn{2}{|c|}{$+\mathrm{S} 9$} \\
\hline & & 1 & 2 & 1 & 2 & 1 & 2 & 1 & 2 \\
\hline \multirow[t]{6}{*}{ AHPlus wet } & $10 \mathrm{mg} /$ plate & & & & & & & & \\
\hline & $5.0 \mathrm{mg} /$ plate & & & & & & & & \\
\hline & $2.5 \mathrm{mg} /$ plate & & & & & & & & \\
\hline & $1.25 \mathrm{mg} / \mathrm{plate}$ & & & & & & & & \\
\hline & $0.625 \mathrm{mg} /$ plate & & & & & & & & \\
\hline & $0.312 \mathrm{mg} /$ plate & & & & & & & & \\
\hline & & & & & & & & & \\
\hline \multirow[t]{6}{*}{ AHPlus set } & $10 \mathrm{mg} /$ plate & & & & & & & & \\
\hline & $5.0 \mathrm{mg} /$ plate & & & & & & & & \\
\hline & $2.5 \mathrm{mg} /$ plate & & & & & & & & \\
\hline & $1.25 \mathrm{mg} /$ plate & & & & & & & & \\
\hline & $0.625 \mathrm{mg} /$ plate & & & & & & & & \\
\hline & $0.312 \mathrm{mg} /$ plate & & & & & & & & \\
\hline & & & & & & & & & \\
\hline \multirow[t]{6}{*}{$\begin{array}{l}\text { RSA Roekoseal } \\
\text { wet }\end{array}$} & $10 \mathrm{mg} /$ plate & & & & & & & & \\
\hline & $5.0 \mathrm{mg} /$ plate & & & & & & & & \\
\hline & $2.5 \mathrm{mg} /$ plate & & & & & & & & \\
\hline & $1.25 \mathrm{mg} /$ plate & & & & & & & & \\
\hline & $0.625 \mathrm{mg} /$ plate & & & & & & & & \\
\hline & $0.312 \mathrm{mg} /$ plate & & & & & & & & \\
\hline \multirow{7}{*}{$\begin{array}{l}\text { RSA Roekoseal } \\
\text { dry } \\
\end{array}$} & & & & & & & & & \\
\hline & $10 \mathrm{mg} /$ plate & & & & & & & & \\
\hline & $5.0 \mathrm{mg} /$ plate & & & & & & & & \\
\hline & $2.5 \mathrm{mg} /$ plate & & & & & & & & \\
\hline & $1.25 \mathrm{mg} /$ plate & & & & & & & & \\
\hline & $0.625 \mathrm{mg} /$ plate & & & & & & & & \\
\hline & $0.312 \mathrm{mg} /$ plate & & & & & & & & \\
\hline
\end{tabular}




\begin{tabular}{|c|c|c|c|c|c|c|c|c|c|}
\hline \multirow{2}{*}{ Sample } & \multirow{3}{*}{ Concentration } & \multicolumn{4}{|c|}{ TA98 } & \multicolumn{5}{|c|}{ TA100 } \\
\hline & & \multicolumn{2}{|c|}{$-\mathrm{S} 9$} & \multicolumn{1}{|c|}{+ S9 } & \multicolumn{2}{|c|}{-S9 } & \multicolumn{2}{c|}{+ S9 } \\
\hline & & 1 & 2 & 1 & 2 & 1 & 2 & 1 & 2 \\
\hline DMSO & $10 \mathrm{ul} /$ plate & & & & & & & & \\
\hline & & & & & & & & & \\
\hline $2 \mathrm{AA}$ & $2.5 \mathrm{ul} /$ plate & & & & & & & & \\
\hline & $5.0 \mathrm{ul} /$ plate & & & & & & & & \\
\hline & & & & & & & & & \\
\hline $1-\mathrm{NP}$ & $1.0 \mathrm{ul} /$ plate & & & & & & & & \\
\hline & $2.5 \mathrm{ul} /$ plate & & & & & & & & \\
\hline & $5.0 \mathrm{ul} /$ plate & & & & & & & & \\
\hline
\end{tabular}

Key: Condition of background lawn

\begin{tabular}{|c|c|c|c|}
\hline Good & Fair & Poor & toxic \\
\hline+ & $/$ & - & $\mathrm{t}$ \\
\hline
\end{tabular}

Table 10. Ames test background lawn condition 
APPENDIX B

Tables of results 


\begin{tabular}{|c|c|c|c|c|}
\hline \multirow{3}{*}{$\begin{array}{l}\text { Dosage } \\
\text { (mg/plate) }\end{array}$} & \multicolumn{4}{|c|}{ Revertants per plate } \\
\hline & \multicolumn{2}{|l|}{ TA98 } & \multicolumn{2}{|l|}{ TA100 } \\
\hline & -S9 & $+\mathrm{S} 9$ & -S9 & $+\mathrm{S} 9$ \\
\hline .312 & 33.6 & 38.5 & 163.3 & 74.5 \\
\hline .625 & 24.3 & 27.5 & 178.0 & 144.0 \\
\hline 1.25 & 15.6 & 24.16 & 220.6 & 76.6 \\
\hline 2.5 & 21.3 & 35.0 & 200.8 & 51.6 \\
\hline 5.0 & 15.5 & 69.0 & 117.3 & 97.5 \\
\hline 10.0 & 77.3 & 85.6 & 76.0 & 76.0 \\
\hline Negative control & 13.1 & 19.6 & 57.9 & 81.4 \\
\hline Positive Control & 653.1 & 908.1 & 861.3 & 1321.5 \\
\hline
\end{tabular}

Table 11. Mutagenicity of DMSO eluates of freshly mixed AHPlus

\begin{tabular}{|c|c|c|c|c|}
\hline \multirow{3}{*}{$\begin{array}{l}\text { Dosage } \\
\text { (mg/plate) }\end{array}$} & \multicolumn{4}{|c|}{ Revertants per plate } \\
\hline & \multicolumn{2}{|l|}{ TA98 } & \multicolumn{2}{|l|}{ TA100 } \\
\hline & -S9 & $+\mathrm{S} 9$ & -S9 & $+\mathrm{S} 9$ \\
\hline .312 & 27.0 & 37.3 & 59.5 & 58.6 \\
\hline .625 & 22.5 & 31.0 & 62.5 & 75.0 \\
\hline 1.25 & 17.8 & 27.3 & 74.5 & 74.5 \\
\hline 2.5 & 23.8 & 35.0 & 138.0 & 71.5 \\
\hline 5.0 & 15.8 & 15.83 & 139.3 & 139.3 \\
\hline 10.0 & 38.3 & 38.3 & 145.5 & 145.5 \\
\hline Negative control & 13.1 & 19.6 & 57.9 & 81.4 \\
\hline Positive Control & 653.1 & 908.1 & 861.3 & 1321.5 \\
\hline
\end{tabular}

Table 12. Mutagenicity of DMSO eluates of AHPlus after setting $24 \mathrm{~h}$. 


\begin{tabular}{|c|c|c|c|c|}
\hline \multirow{3}{*}{$\begin{array}{l}\text { Dosage } \\
\text { (mg/plate) }\end{array}$} & \multicolumn{4}{|c|}{ Revertants per plate } \\
\hline & \multicolumn{2}{|l|}{ TA98 } & \multicolumn{2}{|l|}{ TA100 } \\
\hline & -S9 & $+\mathrm{S} 9$ & -S9 & $+\mathrm{S} 9$ \\
\hline .312 & 17.0 & 19.3 & 79.6 & 91.6 \\
\hline .625 & 11.8 & 21.3 & 73.1 & 78.5 \\
\hline 1.25 & 16.5 & 25.1 & 67.1 & 86.8 \\
\hline 2.5 & 21.3 & 20.8 & 64.1 & 62.6 \\
\hline 5.0 & 19.6 & 22.1 & 54.8 & 74.1 \\
\hline 10.0 & 19.3 & 27.0 & 65.5 & 70.5 \\
\hline Negative control & 13.1 & 19.6 & 57.9 & 81.4 \\
\hline Positive Control & 653.1 & 908.1 & 861.3 & 1321.5 \\
\hline
\end{tabular}

Table 13. Mutagenicity of DMSO eluates of freshly mixed RSA Roekoseal Automix.

\begin{tabular}{|l|c|c|c|c|}
\hline \multirow{2}{*}{$\begin{array}{l}\text { Dosage } \\
\text { (mg/plate) }\end{array}$} & \multicolumn{3}{|l|}{ Revertants per plate } \\
\cline { 2 - 5 } & TA98 & $+\mathrm{S} 9$ & $-\mathrm{S} 9$ & $+\mathrm{S} 9$ \\
\cline { 2 - 5 } & $-\mathrm{S} 9$ & 25.3 & 62.3 & 65.5 \\
.312 & 16.3 & 23.3 & 72.5 & 66.3 \\
.625 & 24.0 & 23.1 & 68.0 & 67.6 \\
1.25 & 17.5 & 21.8 & 60.3 & 69.0 \\
2.5 & 13.5 & 21.5 & 51.8 & 62.6 \\
5.0 & 20.5 & 16.5 & 62.3 & 57.3 \\
10.0 & 21.3 & & & 81.4 \\
Negative control & 13.1 & 19.6 & 57.9 & 1321.5 \\
Positive Control & 653.1 & 908.1 & 861.3 & \\
\hline
\end{tabular}

Table 14. Mutagenicity of DMSO eluates of RSA Roekoseal Automix after setting $24 \mathrm{~h}$. 
Comparisons with a control using Dunnett's Method

\begin{tabular}{|ll|}
\hline Alpha $=0.05$ & \\
Abs(Dif) - LSD & Control \\
& \\
$.312 \mathrm{mg} / .1 \mathrm{ul}$ & -110.742 \\
$.625 \mathrm{mg} / .1 \mathrm{ul}$ & -54.909 \\
$1.25 \mathrm{mg} / .1 \mathrm{ul}$ & -112.909 \\
$2.5 \mathrm{mg} / .1 \mathrm{ul}$ & -87.909 \\
$5 \mathrm{mg} / .1 \mathrm{ul}$ & -101.409 \\
$10 \mathrm{mg} / .1 \mathrm{ul}$ & -112.242 \\
control & -117.575 \\
& \\
Positive values show pairs of means that are significantly different. \\
\hline
\end{tabular}

Table 15. Statistical analysis of AHPlus after mixing in TA100 with S9

Comparisons with a control using Dunnett's Method

\begin{tabular}{|ll|}
\hline Alpha $=0.05$ & \\
& \\
Abs(Dif) - LSD & Control \\
& \\
$.312 \mathrm{mg} / .1 \mathrm{ul}$ & -7.273 \\
$.625 \mathrm{mg} / .1 \mathrm{ul}$ & 7.393 \\
$1.25 \mathrm{mg} / .1 \mathrm{ul}$ & 50.060 \\
$2.5 \mathrm{mg} / .1 \mathrm{ul}$ & 30.227 \\
$5 \mathrm{mg} / .1 \mathrm{ul}$ & -53.273 \\
$10 \mathrm{mg} / .1 \mathrm{ul}$ & -94.607 \\
control & -112.773 \\
& \\
Positive values show pairs of means that are significantly different. \\
\hline
\end{tabular}

Table 16. Statistical analysis of AHPlus after mixing in TA100 without S9 
Comparisons with a control using Dunnett's Method

\begin{tabular}{|lc|}
\hline Alpha $=0.05$ & \\
Abs(Dif) - LSD & Control \\
& \\
$.312 \mathrm{mg} / .1 \mathrm{ul}$ & -17.096 \\
$.625 \mathrm{mg} / .1 \mathrm{ul}$ & -33.4293 \\
$1.25 \mathrm{mg} / .1 \mathrm{ul}$ & -32.9293 \\
$2.5 \mathrm{mg} / .1 \mathrm{ul}$ & -29.9293 \\
$5 \mathrm{mg} / .1 \mathrm{ul}$ & 18.2373 \\
$10 \mathrm{mg} / .1 \mathrm{ul}$ & 24.4040 \\
control & -39.7627 \\
& \\
Positive values show pairs of means that are significantly different. \\
\hline
\end{tabular}

Table17. Statistical analysis of AHPlus after setting 24h in TA100 with S9.

Comparisons with a control using Dunnett's Method

\begin{tabular}{|lc|}
\hline Alpha $=0.05$ & \\
& \\
Abs(Dif) - LSD & Control \\
& \\
$.312 \mathrm{mg} / .1 \mathrm{ul}$ & -32.1554 \\
$.625 \mathrm{mg} / .1 \mathrm{ul}$ & -29.1554 \\
$1.25 \mathrm{mg} / .1 \mathrm{ul}$ & -17.1554 \\
$2.5 \mathrm{mg} / .1 \mathrm{ul}$ & 46.3446 \\
$5 \mathrm{mg} / .1 \mathrm{ul}$ & 47.6779 \\
$10 \mathrm{mg} / .1 \mathrm{ul}$ & 53.8446 \\
control & -33.8221 \\
& \\
Positive values show pairs of means that are significantly different. \\
\hline
\end{tabular}

Table18. Statistical analysis of AHPlus after setting $24 \mathrm{~h}$ in TA100 without S9. 
Comparison with a control using Dunnett's Method

\begin{tabular}{|lc|}
\hline Alpha $=0.05$ & \\
& \\
Abs(Dif) - LSD & Control \\
& \\
$.312 \mathrm{mg} / .1 \mathrm{ul}$ & 11.3132 \\
$.625 \mathrm{mg} / .1 \mathrm{ul}$ & 1.9799 \\
$1.25 \mathrm{mg} / .1 \mathrm{ul}$ & -6.6868 \\
$2.5 \mathrm{mg} / .1 \mathrm{ul}$ & -1.0201 \\
$5 \mathrm{mg} / .1 \mathrm{ul}$ & -6.8534 \\
$10 \mathrm{mg} / .1 \mathrm{ul}$ & 54.9799 \\
control & -9.1868 \\
& \\
Positive values show pairs of means that are significantly different.
\end{tabular}

Table19. Statistical analysis of AHPlus after mixing in TA98 without S9.

Comparison with a control using Dunnett's Method

\begin{tabular}{|cc}
\hline Alpha $=0.05$ & \\
& \\
Abs(Dif) - LSD & Control \\
& \\
$.312 \mathrm{mg} / .1 \mathrm{ul}$ & -108.294 \\
$.625 \mathrm{mg} / .1 \mathrm{ul}$ & -119.294 \\
$1.25 \mathrm{mg} / .1 \mathrm{ul}$ & -122.628 \\
$2.5 \mathrm{mg} / .1 \mathrm{ul}$ & -111.794 \\
$5 \mathrm{mg} / .1 \mathrm{ul}$ & -77.794 \\
$10 \mathrm{mg} / .1 \mathrm{ul}$ & 61.128 \\
control & -127.128
\end{tabular}

Positive values show pairs of means that are significantly different.

Table 20. Statistical analysis of AHPlus after mixing in TA98 with S9. 
Comparison with a control using Dunnett's Method

\begin{tabular}{|lc|}
\hline Alpha $=0.05$ & \\
Abs(Dif) - LSD & Control \\
& \\
$.312 \mathrm{mg} / .1 \mathrm{ul}$ & 2.0316 \\
$.625 \mathrm{mg} / .1 \mathrm{ul}$ & -2.4684 \\
$1.25 \mathrm{mg} / .1 \mathrm{ul}$ & -7.1351 \\
$2.5 \mathrm{mg} / .1 \mathrm{ul}$ & -1.1351 \\
$5 \mathrm{mg} / .1 \mathrm{ul}$ & -9.1351 \\
$10 \mathrm{mg} / .1 \mathrm{ul}$ & 13.3649 \\
control & -11.8017 \\
& \\
Positive values show pairs of means that are significantly different.
\end{tabular}

Table 21. Statistical analysis of AHPlus after setting 24h in TA98 without S9

Comparison with a control using Dunnett's Method

\begin{tabular}{|ll|}
\hline Alpha $=0.05$ & \\
Abs(Dif) - LSD & Control \\
& \\
$.312 \mathrm{mg} / .1 \mathrm{ul}$ & -0.5745 \\
$.625 \mathrm{mg} / .1 \mathrm{ul}$ & -6.9079 \\
$1.25 \mathrm{mg} / .1 \mathrm{ul}$ & -10.5745 \\
$2.5 \mathrm{mg} / .1 \mathrm{ul}$ & -2.9079 \\
$5 \mathrm{mg} / .1 \mathrm{ul}$ & -14.4079 \\
$10 \mathrm{mg} / .1 \mathrm{ul}$ & 0.4255 \\
control & -18.2412 \\
& \\
Positive values show pairs of means that are significantly different. \\
\hline
\end{tabular}

Table 22. Statistical analysis of AHPlus after setting 24h in TA 98 with S9. 
Comparisons with a control using Dunnett's Method

\begin{tabular}{|ll|}
\hline Alpha $=0.05$ & \\
Abs(Dif) - LSD & Control \\
& \\
$.312 \mathrm{mg} / .1 \mathrm{ul}$ & -9.9580 \\
$.625 \mathrm{mg} / .1 \mathrm{ul}$ & -12.4580 \\
$1.25 \mathrm{mg} / .1 \mathrm{ul}$ & -10.4580 \\
$2.5 \mathrm{mg} / .1 \mathrm{ul}$ & -5.6247 \\
$5 \mathrm{mg} / .1 \mathrm{ul}$ & -7.2913 \\
$10 \mathrm{mg} / .1 \mathrm{ul}$ & -7.6247 \\
control & -13.7913 \\
& \\
Positive values show pairs of means that are significantly different.
\end{tabular}

Table 23. Statistical analysis of RSA Roekoseal Automix after mixing in TA98 without S9.

Comparisons with a control using Dunnett's Method

\begin{tabular}{|ll|}
\hline Alpha $=0.05$ & \\
& \\
Abs(Dif) - LSD & Control \\
& \\
$.312 \mathrm{mg} / .1 \mathrm{ul}$ & -12.0441 \\
$.625 \mathrm{mg} / .1 \mathrm{ul}$ & -10.7107 \\
$1.25 \mathrm{mg} / .1 \mathrm{ul}$ & -6.8774 \\
$2.5 \mathrm{mg} / .1 \mathrm{ul}$ & -11.2107 \\
$5 \mathrm{mg} / .1 \mathrm{ul}$ & -9.8774 \\
$10 \mathrm{mg} / .1 \mathrm{ul}$ & -5.0441 \\
control & -12.3774 \\
& \\
Positive values show pairs of means that are significantly different. \\
\hline
\end{tabular}

Table 24. Statistical analysis of RSA Roekoseal Automix after mixing in TA98 with S9. 
Comparison with a control using Dunnett's Method

\begin{tabular}{|ll|}
\hline Alpha $=0.05$ & \\
& Control \\
& \\
$.312 \mathrm{mg} / .1 \mathrm{ul}(\mathrm{Dif})-\mathrm{LSD}$ & -14.9569 \\
$.625 \mathrm{mg} / .1 \mathrm{ul}$ & -16.9569 \\
$1.25 \mathrm{mg} / .1 \mathrm{ul}$ & -17.1235 \\
$2.5 \mathrm{mg} / .1 \mathrm{ul}$ & -18.4569 \\
$5 \mathrm{mg} / .1 \mathrm{ul}$ & -18.7902 \\
$10 \mathrm{mg} / .1 \mathrm{ul}$ & -17.4569 \\
control & -20.6235 \\
& \\
Positive values show pairs of means that are significantly different.
\end{tabular}

Table 25. Statistical analysis of RSA Roekoseal Automix after setting $24 \mathrm{~h}$ in TA98 with S9.

Comparison with control using Dunnett's Method

\begin{tabular}{|ll|}
\hline Alpha $=0.05$ & \\
Abs(Dif) - LSD & Control \\
& \\
$.312 \mathrm{mg} / .1 \mathrm{ul}$ & -12.0953 \\
$.625 \mathrm{mg} / .1 \mathrm{ul}$ & -4.4286 \\
$1.25 \mathrm{mg} / .1 \mathrm{ul}$ & -10.9286 \\
$2.5 \mathrm{mg} / .1 \mathrm{ul}$ & -14.9286 \\
$5 \mathrm{mg} / .1 \mathrm{ul}$ & -7.9286 \\
$10 \mathrm{mg} / .1 \mathrm{ul}$ & -7.0953 \\
control & -15.2620 \\
& \\
Positive values show pairs of means that are significantly different.
\end{tabular}

Table 26. Statistical analysis of RSA Roekoseal Automix after setting $24 \mathrm{~h}$ in TA98 without S9. 
Comparison with a control using Dunnett's Method

\begin{tabular}{|lc|}
\hline Alpha $=0.05$ & \\
& \\
Abs(Dif) - LSD & Control \\
& \\
$.312 \mathrm{mg} / .1 \mathrm{ul}$ & -23.7418 \\
$.625 \mathrm{mg} / .1 \mathrm{ul}$ & -31.2418 \\
$1.25 \mathrm{mg} / .1 \mathrm{ul}$ & -28.5751 \\
$2.5 \mathrm{mg} / .1 \mathrm{ul}$ & -15.4084 \\
$5 \mathrm{mg} / .1 \mathrm{ul}$ & -26.9084 \\
$10 \mathrm{mg} / .1 \mathrm{ul}$ & -23.2418 \\
control & -34.0751 \\
& \\
Positive values show pairs of means that are significantly different.
\end{tabular}

Table 27. Statistical analysis of RSA Roekoseal Automix after mixing in TA100 with S9.

Comparison with a control using Dunnett's Method

\begin{tabular}{|c|c|}
\hline Alpha $=0.05$ & \\
\hline $\operatorname{Abs}(\mathrm{Dif})-\mathrm{LSD}$ & Control \\
\hline $.312 \mathrm{mg} / .1 \mathrm{ul}$ & -2.4291 \\
\hline $.625 \mathrm{mg} / .1 \mathrm{ul}$ & -4.0709 \\
\hline $1.25 \mathrm{mg} / .1 \mathrm{ul}$ & -10.0709 \\
\hline $2.5 \mathrm{mg} / .1 \mathrm{ul}$ & -13.0709 \\
\hline $5 \mathrm{mg} / .1 \mathrm{ul}$ & -16.4042 \\
\hline $10 \mathrm{mg} / .1 \mathrm{ul}$ & -11.7376 \\
\hline control & -19.4042 \\
\hline
\end{tabular}

Positive values show pairs of means that are significantly different.

Table 28. Statistical analysis of RSA Roekoseal Automix after mixing in TA100 without S9. 
Comparison with a control using Dunnett's Method

\begin{tabular}{|lc|}
\hline Alpha $=0.05$ & \\
Abs(Dif) - LSD & Control \\
& \\
$.312 \mathrm{mg} / .1 \mathrm{ul}$ & -19.9727 \\
$.625 \mathrm{mg} / .1 \mathrm{ul}$ & -20.8060 \\
$1.25 \mathrm{mg} / .1 \mathrm{ul}$ & -22.1393 \\
$2.5 \mathrm{mg} / .1 \mathrm{ul}$ & -23.4727 \\
$5 \mathrm{mg} / .1 \mathrm{ul}$ & -17.1393 \\
$10 \mathrm{mg} / .1 \mathrm{ul}$ & -11.8060 \\
control & -35.8060 \\
& \\
Positive values show pairs of means that are significantly different.
\end{tabular}

Table 29. Statistical analysis of RSA Roekoseal Automix after setting 24h in TA100 with S9.

Comparison with a control using Dunnett's Method

\begin{tabular}{|ll|}
\hline Alpha $=0.05$ & \\
Abs(Dif) - LSD & Control \\
& \\
$.312 \mathrm{mg} / .1 \mathrm{ul}$ & -21.0723 \\
$.625 \mathrm{mg} / .1 \mathrm{ul}$ & -10.9056 \\
$1.25 \mathrm{mg} / .1 \mathrm{ul}$ & -15.4056 \\
$2.5 \mathrm{mg} / .1 \mathrm{ul}$ & -23.0723 \\
$5 \mathrm{mg} / .1 \mathrm{ul}$ & -19.5723 \\
$10 \mathrm{mg} / .1 \mathrm{ul}$ & -21.0723 \\
control & -25.5723 \\
& \\
Positive values show pairs of means that are significantly different.
\end{tabular}

Table 30. Statistical analysis of RSA Roekoseal Automix after setting 24h in TA100 without S9. 


\begin{tabular}{|lccc|}
\hline \multicolumn{4}{|c|}{ ANALYSIS OF VARIANCE FOR TA98 AND TA100 } \\
\hline Level & Least square mean & Std error & Mean \\
\hline TA100 & 89.4791 & 1.88 & 89.4792 \\
\hline TA98 & 26.7534 & 1.88 & 26.7535 \\
\hline
\end{tabular}

Table 31. Analysis of variance for TA98 and TA100. 
APPENDIX C

Diagrams 


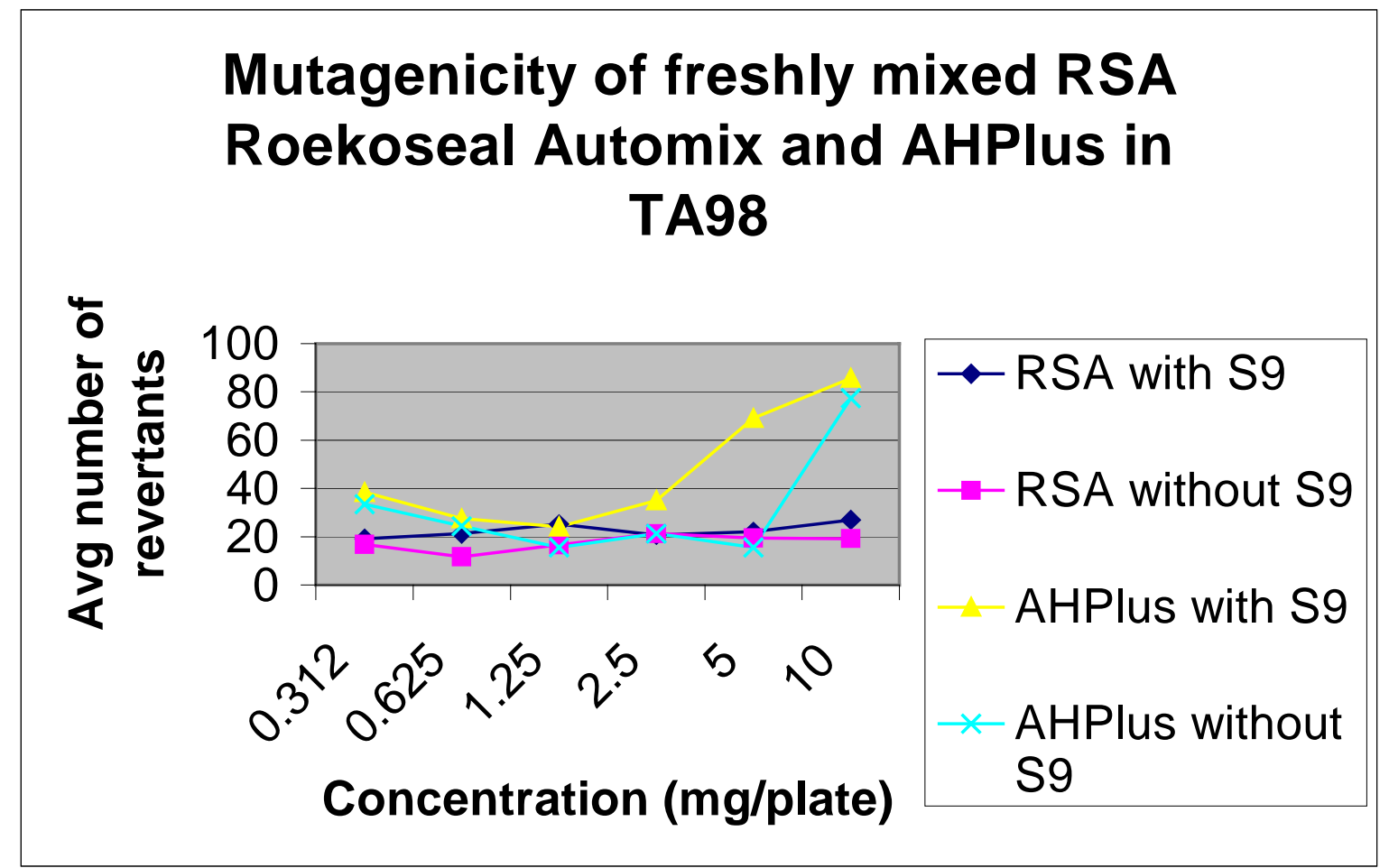

Diagram 1. Mutagenicity of freshly mixed RSA Roekoseal and AHPlus in TA98

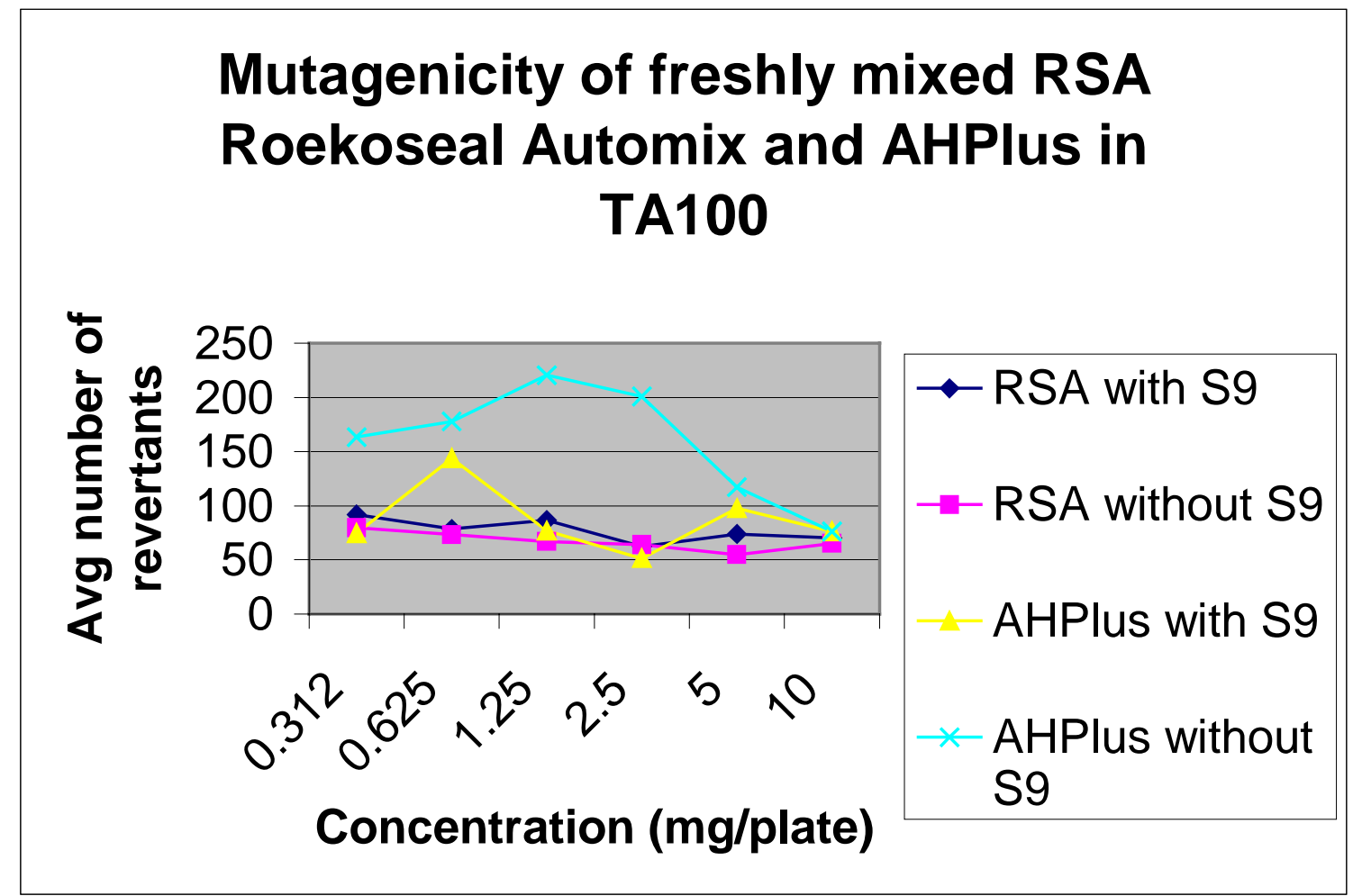

Diagram 2. Mutagenicity of freshly mixed RSA Roekoseal and AHPlus in TA100. 


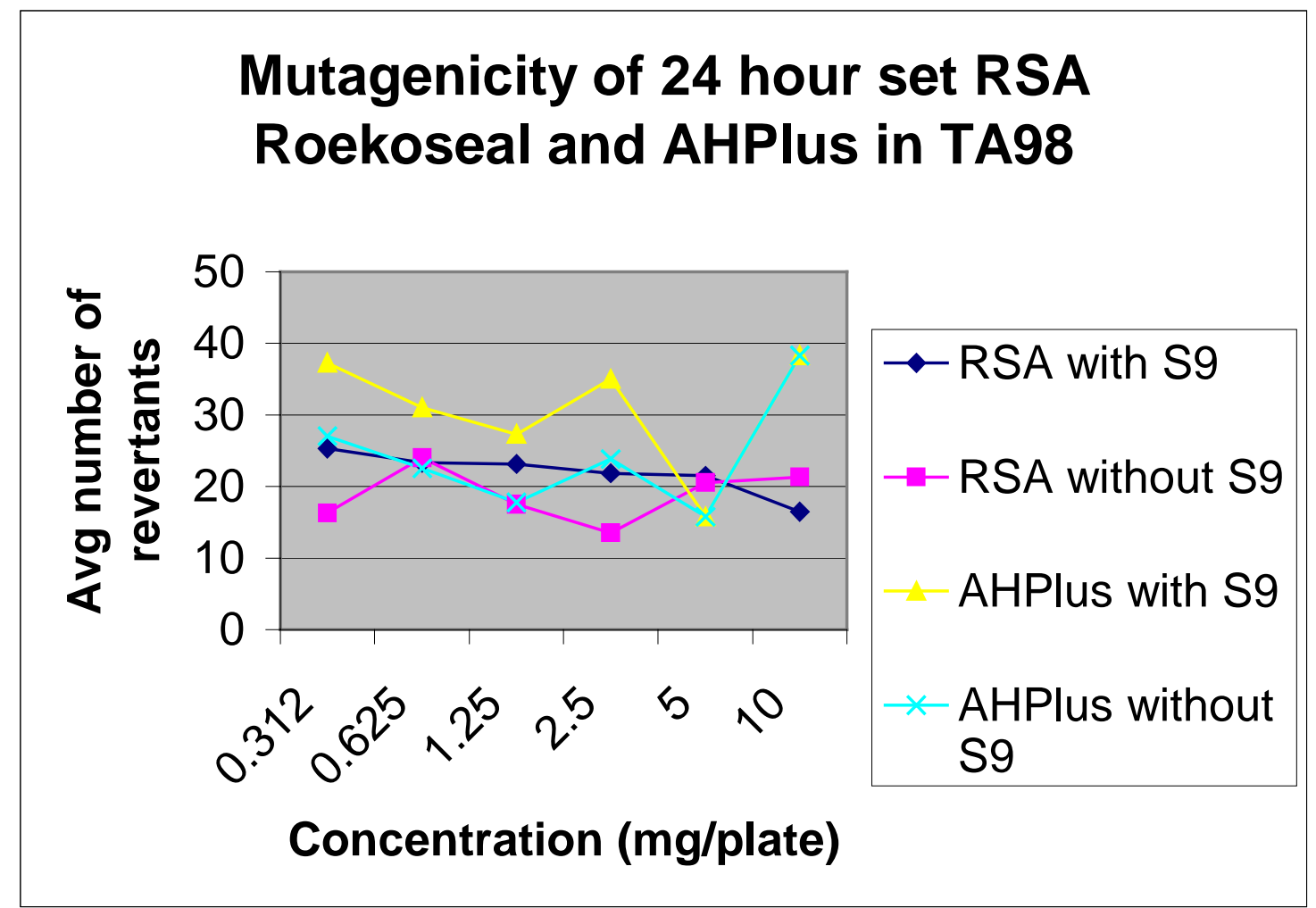

Diagram 3. Mutagenicity of 24h set RSA Roekoseal and AHPlus in TA98.

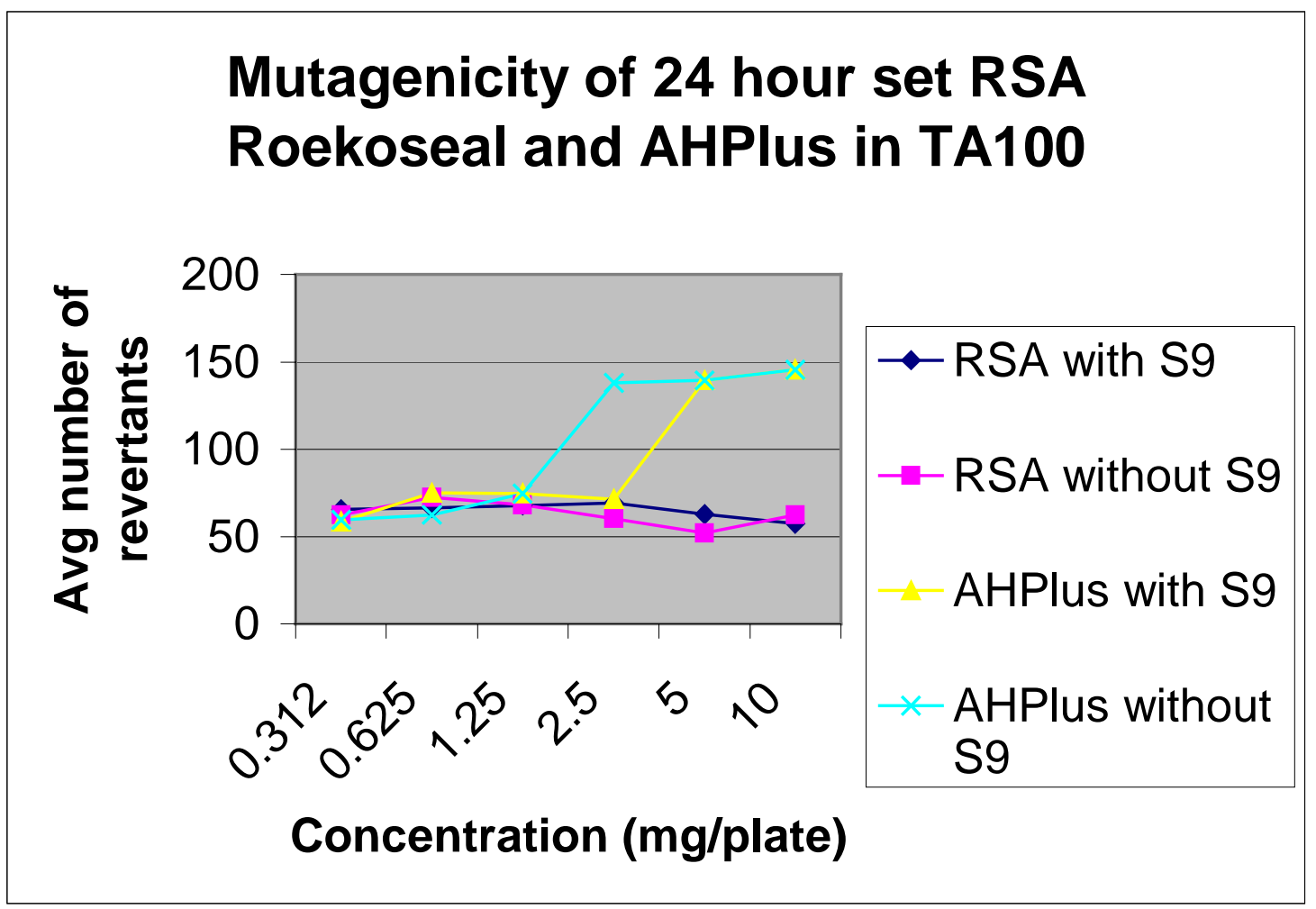

Diagram 4. Mutagenicity of $24 \mathrm{~h}$ set RSA Roekoseal and AHPlus in TA100. 


\section{CURRICULUM VITAE}

\section{BIOGRAPHICAL DATA}

Name: Joseph A. Wateska

Date of Birth: December 4, 1969

Place of Birth: Pittsburgh, Pennsylvania

II. EDUCATION:

Pennsylvania State University

$1988-1991$

University of Pittsburgh

D.M.D.

1995

United State Navy

GPR

1995 - 1996

United States Navy

Lieutenant

1995 - 1999

West Virginia University

M.S.

2001

\section{EMPLOYMENT}

$1995-1999$

Dentist, United States Navy 